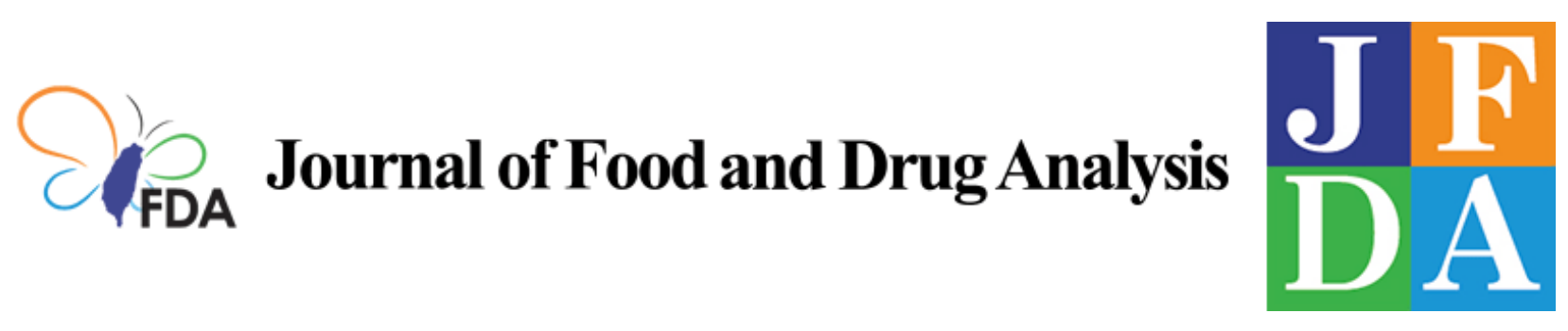

Volume 29 | Issue 4

Article 5

2021

\title{
Anti-lymphangiogenic diterpenes from the bark of Calocedrus macrolepis var. formosana
}

Follow this and additional works at: https://www.jfda-online.com/journal

Part of the Food Science Commons, Medicinal Chemistry and Pharmaceutics Commons, Pharmacology Commons, and the Toxicology Commons

(c) (i) $9 \bigcirc$

This work is licensed under a Creative Commons Attribution-Noncommercial-No Derivative Works 4.0 License.

\section{Recommended Citation}

Lee, Tzong-Huei; Hsieh, Chin-Lin; Wu, Ho-Cheng; Wang, Shih-Wei; Yu, Chen-Lin; Hsiao, George; Cheng, Ming-Jen; Hsieh, Wen-Tsong; and Kuo, Yueh-Hsiung (2021) "Anti-lymphangiogenic diterpenes from the bark of Calocedrus macrolepis var. formosana," Journal of Food and Drug Analysis: Vol. 29 : Iss. 4 , Article 5 .

Available at: https://doi.org/10.38212/2224-6614.3375

This Original Article is brought to you for free and open access by Journal of Food and Drug Analysis. It has been accepted for inclusion in Journal of Food and Drug Analysis by an authorized editor of Journal of Food and Drug Analysis. 


\title{
Anti-lymphangiogenic diterpenes from the bark of Calocedrus macrolepis var. formosana
}

\author{
Tzong-Huei Lee ${ }^{\mathrm{a}, 1}$, Chin-Lin Hsieh ${ }^{\mathrm{b}, \mathrm{c}}$, Ho-Cheng $\mathrm{Wu}^{\mathrm{a}}$, Shih-Wei Wang ${ }^{\mathrm{d}, \mathrm{e}, \mathrm{f}}$, \\ Chen-Lin $\mathrm{Yu}^{\mathrm{d}}{ }^{\mathrm{e}}$, George Hsiao ${ }^{\mathrm{g}}$, Ming-Jen Cheng ${ }^{\mathrm{h}}$, \\ Wen-Tsong Hsieh ${ }^{\mathrm{i}, 1}$, Yueh-Hsiung Kuo ${ }^{\mathrm{j}, \mathrm{k}, \mathrm{l}, *}$
}

\author{
${ }^{a}$ Institute of Fisheries Science, National Taiwan University, Taipei, 106, Taiwan \\ ${ }^{\mathrm{b}}$ Department of Chemistry, National Taiwan University, Taipei, 106, Taiwan \\ ${ }^{c}$ Department of Disaster Management, Taiwan Police College, Taipei, 116, Taiwan \\ ${ }^{\mathrm{d}}$ Institute of Biomedical Sciences, MacKay Medical College, New Taipei City, 252, Taiwan \\ e Department of Medicine, Mackay Medical College, New Taipei City, 252, Taiwan \\ ${ }^{\mathrm{f}}$ Graduate Institute of Natural Products, College of Pharmacy, Kaohsiung Medical University, Kaohsiung, Taiwan \\ ${ }^{\mathrm{g}}$ Graduate Institute of Medical Sciences, College of Medicine, Taipei Medical University, Taipei, Taiwan \\ ${ }^{\mathrm{h}}$ Bioresource Collection and Research Center (BCRC), Food Industry Research and Development Institute (FIRDI), Hsinchu, 300, \\ Taiwan \\ ${ }^{i}$ Department of Pharmacology, China Medical University, Taichung, 404, Taiwan \\ ${ }^{j}$ Department of Chinese Pharmaceutical Sciences and Chinese Medicine Resources, China Medical University, Taichung, 404, Taiwan \\ ${ }^{\mathrm{k}}$ Chinese Medicine Research Center, China Medical University, Taichung, 404, Taiwan \\ ${ }^{1}$ Department of Biotechnology, Asia University, Taichung, 413, Taiwan
}

\begin{abstract}

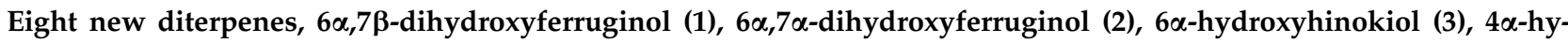
droxy-7-oxo-18-norabieta-8,11,13-trien-4 $\alpha$-ol (4a), 15,16-dehydrosugiol (5), 7-methoxy-6,7-secoabieta-8,11,13-triene-6,12diol (6), 7 $\alpha$-acetoxyabieta-8,12-diene-11,14-dione (7), 7 $\alpha$-butyloxyethyloxyabieta-8,12-diene-11,14-dione (8), along with four known compounds, 6,7-dehydroferruginol (9), 12-hydroxy-6,7-secoabieta-8,11,13-triene-6,7-dial (10), 7 $\alpha$-11-dihydroxy-12-methoxy-8,11,13-abietatriene (11), and 11,14-dihydroxy-8,11,13-abietatrien-7-one (12) were successfully isolated from the bark of Calocedrus macrolepis var. formosana. The structures of all isolates were elucidated by physical data (appearance, UV, IR, optical rotation) and spectroscopic data (1D, 2D NMR, and HREIMS). Compounds 9, 10, 11, and 12 showed promising growth-inhibitory effect on human lymphatic endothelial cells (LECs). Among these compounds, compound 10 exerted the most potent anti-lymphangiogenesis property by suppressing cell growth and tube formation of LECs. In conclusion, the results revealed the anti-lymphangiogenic potentials of Formosan C. macrolepis var. formosana.
\end{abstract}

Keywords: Anti-lymphangiogenesis, Calocedrus macrolepis var.formosana, Diterpenes

\section{Introduction}

ancer is one of the largest health problems across the world. According to the GLOBOCAN, 18.1 million new cancer cases were diagnosed and 9.6 million cancer-related deaths in 2018 [1]. Although there are many types of cancer treatment, the common types of anti-cancer options such as chemotherapy and radiotherapy usually have severe side effects, causing low medication adherence and treatment failure. The high mortality rates of cancer patients are not only associated with the occurrence of primary tumors but, highly by the metastatic spread of tumor cells from the original site to other organs [2]. In the tumor microenvironment, primary tumors will secrete growth factors

Received 4 June 2021; revised 3 August 2021; accepted 18 August 2021.

Available online 15 December 2021.

* Corresponding author at: Department of Chinese Pharmaceutical Sciences and Chinese Medicine Resources, China Medical University, No. 100, Sec. 1, Jingmao Rd., Taichung, 404, Taiwan.

E-mail address: kuoyhlab@gmail.com (Y.-H. Kuo).

These authors contributed equally to this work. 
to format new lymphatic vessels and help cancer cells disseminates to other lymph node [3]. Thus, the development of a target cancer therapy with antilymphangiogenic activity is an effective strategy for improving patient survival rates.

The Calocedrus species (Cupressaceae) comprises three species with acceptable names, mainly distributed in western north American, Taiwan, and southwestern China [4]. The major component, hinokiol, and other physico-chemical properties of this plant improves the resistance to decay and wood durability $[5,6]$. Previous studies of Calocedrus macrolepis Kurz var. formosana (Florin) W. C. Cheng \& L. K. Fu identified various classes of chemical constituents, such as fatty acids, monoterpenes, shonanic acids [7-9], sesquiterpenes [10], diterpenes [4,11-15], furanones [10], sesquarterpene $\left(C_{35}\right)[16,17]$, and lignans [4]. Some of them showed cytotoxicity [4,16-18], anti-inflammatory [19], antioxidant [19,20], anti-microbial [20], anti-plant pathogenic fungi [21], and arteriosclerosis prevention [14] activity. Our long-term studies on the C. macrolepis var. formosana have identified plentiful secondary metabolites with cytotoxicity toward human oral epidermoid carcinoma KB cells [13,16,17], which prompted us to further explore its ingredients as the source of cytotoxic compounds.

With a series of isolation and purification process, we successfully isolated twelve diterpenes from the bark of $C$. macrolepis var. formosana in current study. Diterpenoids are well-known for its cytotoxicity toward different kind of tumors. Surprisingly, diterpenes exhibited anti-lymphangiogenic activity, a novel concept for targeting tumor cell metastasis in previous investigation [22]. Thus, to confirm the relationship between diterpenes and anti-lymphangiogenic activity, as well as to broaden the pharmacological property of diterpenes, the antilymphangiogenic activity of isolated compounds in this study was evaluated. Here, we report the structure elucidation of eight new diterpenes along with four known compounds from the bark of $C$. macrolepis var. formosana (Fig. 1). Among these, compounds 9, 10, 11, and 12 exhibited anti-lymphangiogenic activity.

\section{Materials and methods}

\subsection{General experimental procedures}

Optical rotations were measured on a Jasco DIP1000 Digital polarimeter (Jasco, Kyoto, Japan), and IR spectra (neat) were acquired with a Perkin-Elmer 983G spectrometer (Perkin-Elmer, Waltham, MA, USA). The $1 \mathrm{D}\left({ }^{1} \mathrm{H},{ }^{13} \mathrm{C}, \mathrm{DEPT}\right)$ and $2 \mathrm{D}$ (COSY,
NOESY, ROESY, HSQC, HMBC) NMR spectra were obtained from a Burcher DMX-500 spectrometer (Bruker Inc., Bremen, Germany) operated at $500\left({ }^{1} \mathrm{H}\right)$ and $125 \mathrm{MHz}\left({ }^{13} \mathrm{C}\right)$. The HRESIMS data were generated at the Mass Spectrometry Laboratory by a JEOL JMS-H110 mass spectrometer (FAB-MS) (JEOL, Inc. Tokyo, Japan). Extracts were chromatographed on silica gel (Merk 70-230 mesh, 230-400 mesh, ASTM) and purified with a semipreparative normal-phase HPLC column (Merck LichroCART $250 \times 10 \mathrm{~mm}$, $7 \mu \mathrm{m}$, LiChrosorb Si 60) taken on LDC Analytical-III.

\subsection{Plant materials}

The dried bark of $C$. macrolepis var. formosana was collected in Nan-Tou, Taiwan (Aug., 1998) and identified by Prof. Shang-Tzen Chang in the Department of Forestry, National Taiwan University. A voucher specimen (No. 223133) has been deposited in the Herbarium of the Department of Life Science, National Taiwan University, Taipei, Taiwan.

\subsection{Extraction and isolation}

The dried bark of C. macrolepis var. formosana $(16 \mathrm{~kg})$ was extracted with acetone ( $140 \mathrm{~L})$ at room temperature (two times, 7 days/each time). The acetone extract $(1.8 \mathrm{~kg})$ was suspended in $\mathrm{H}_{2} \mathrm{O}$, then partitioned with EtOAc. The EtOAc layer (734 g) was subjected to open column chromatography $\left(\mathrm{SiO}_{2} 60,70-230\right.$ mesh; Merck), and purified by repeated normal-phase HPLC with mixtures of $n$-hexane and EtOAc as eluents. Compounds $2(\mathrm{H} / \mathrm{E}=6: 4,2.4 \mathrm{mg}), 3(\mathrm{H} / \mathrm{E}=6: 4$, $1.5 \mathrm{mg}), 4 \mathrm{a}(\mathrm{H} / \mathrm{E}=7: 3,2.1 \mathrm{mg}), 5(\mathrm{H} / \mathrm{E}=4: 1,1.5 \mathrm{mg}), 6$ $(\mathrm{H} / \mathrm{E}=4: 1,1.9 \mathrm{mg}), 7(\mathrm{H} / \mathrm{E}=7: 3,2.0 \mathrm{mg}), 8(\mathrm{H} / \mathrm{E}=9: 1$, $2.2 \mathrm{mg}), 9(\mathrm{H} / \mathrm{E}=4: 1,1.3 \mathrm{mg}), 10(\mathrm{H} / \mathrm{E}=7: 3,4.5 \mathrm{mg}), 11$ $(\mathrm{H} / \mathrm{E}=4: 1,9.3 \mathrm{mg}), 12(\mathrm{H} / \mathrm{E}=6: 4,6.3 \mathrm{mg})$, and $13(\mathrm{H} /$ $\mathrm{E}=9: 1,10.2 \mathrm{mg}$ ) were obtained using above solvent systems as mobile phase, respectively.

\subsection{Spectral data}

$6 \alpha, 7 \beta$-Dihydroxyferruginol (1): Gum; $[\alpha]_{\mathrm{D}}^{25}+35.1$ (c 0.2, acetone); UV (MeOH) $\lambda_{\max }(\log \epsilon) 235$ (3.39), 280 (3.23) $\mathrm{nm}$; IR (neat) $v_{\max } 3365,1617,1582,1500$, $1462 \mathrm{~cm}^{-1}$; HREIMS $\mathrm{m} / z$ 318.2197 $[\mathrm{M}]^{+}$(calcd. for $\mathrm{C}_{20} \mathrm{H}_{30} \mathrm{O}_{3}$ 318.2195); ${ }^{1} \mathrm{H}\left(500 \mathrm{MHz}\right.$, acetone- $\left.d_{6}\right)$ and ${ }^{13} \mathrm{C}$ NMR (125 MHz, acetone- $\left.d_{6}\right)$ : see Tables 1 and 2. $6 \alpha, 7 \alpha$-Dihydroxyferruginol (2): Gum; $[\alpha]_{\mathrm{D}}^{25}+25.7$ (c 0.5, acetone); UV (MeOH) $\lambda_{\max }(\log \epsilon) 225$ (3.67), 283 $(3.25) \mathrm{nm}$; IR (neat) $v_{\max } 3367,1618,1582,1508 \mathrm{~cm}^{-1}$; HREIMS $\mathrm{m} / \mathrm{z} 318.2197[\mathrm{M}]^{+}$(calcd. for $\mathrm{C}_{20} \mathrm{H}_{30} \mathrm{O}_{3}$ 318.2196); ${ }^{1} \mathrm{H}\left(500 \mathrm{MHz}\right.$, acetone- $\left.d_{6}\right)$ and ${ }^{13} \mathrm{C}$ NMR (125 MHz, acetone- $d_{6}$ ): see Tables 1 and 2. 


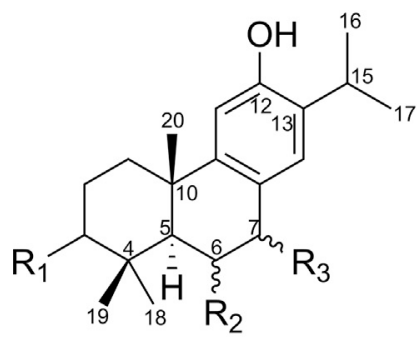

$$
\begin{aligned}
& \text { 1, } \mathrm{R}_{1}=\mathrm{H}, \mathrm{R}_{2}=\alpha-\mathrm{OH}, \mathrm{R}_{3}=\beta-\mathrm{OH} \\
& \text { 2, } \mathrm{R}_{1}=\mathrm{H}, \mathrm{R}_{2}=\mathrm{R}_{3}=\alpha-\mathrm{OH}
\end{aligned}
$$$$
\text { 3, } \mathrm{R}_{1}=\beta-\mathrm{OH}, \mathrm{R}_{2}=\alpha-\mathrm{OH}, \mathrm{R}_{3}=\mathrm{H}
$$

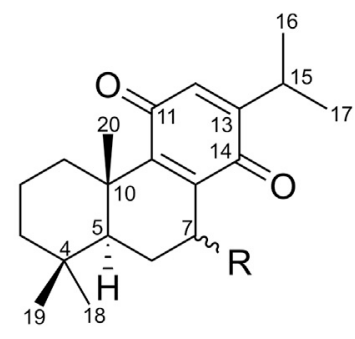

$7, \mathrm{R}=\alpha-\mathrm{OCOCH}_{3}$ $8, \mathrm{R}=\alpha-\mathrm{OC}_{2} \mathrm{H}_{4} \mathrm{OC}_{3} \mathrm{H}_{6} \mathrm{CH}_{3}$<smiles>[R]C1(C)CCC[C@@]2(C)c3cc(O)c(C([3H])[3H])cc3C(=O)C[C@]12C</smiles>

$$
\text { 4a, } \mathrm{R}=\mathrm{OH}
$$
4b, $\mathrm{R}=\mathrm{CH}_{3}$<smiles>CC(C)c1cc2c(cc1O)[C@]1(C)CCCC(C)(C)[C@@H]1C=C2</smiles>

9

Fig. 1. Chemical structures of compounds 1-12.<smiles>C[C@]12CCCC(F)(F)[C@@H]1CC(=O)c1cc(C(=O)I)c(O)cc12</smiles><smiles>[R2]c1c(C(C)C)cc2c(c1O)[C@]1(C)CCCC(C)(C)[C@@H]1CC2[R]</smiles>

$11, \mathrm{R}_{1}=\alpha-\mathrm{OH}, \mathrm{R}_{2}=\mathrm{OCH}_{3}$ $12, R_{1}==O, R_{2}=H$<smiles>[R]Cc1cc(C(C)C)c(O)cc1[C@]1(C)CCCC(C)(C)[C@H]1C[R]</smiles>

6, $\mathrm{R}_{1}=\mathrm{OH}, \mathrm{R}_{2}=\mathrm{OCH}_{3}$ 10, $\mathrm{R}_{1}=\mathrm{R}_{2}=\mathrm{CHO}$
$6 \alpha$-Hydroxyhinokiol (3): Gum; $[\alpha]_{\mathrm{D}}^{25}+9.0$ (c 0.54 , $\mathrm{MeOH}) ; \mathrm{UV}(\mathrm{MeOH}) \lambda_{\max }(\log \epsilon) 218$ (3.67), 280 (3.31) $\mathrm{nm}$; IR (neat) $v_{\max } 3368,1616,1505 \mathrm{~cm}^{-1}$; HREIMS $\mathrm{m} /$ $z 318.2200[\mathrm{M}]^{+}$(calcd. for $\mathrm{C}_{20} \mathrm{H}_{30} \mathrm{O}_{3} 318.2189$ ); ${ }^{1} \mathrm{H}$ (500 MHz, acetone- $d_{6}$ ) and ${ }^{13} \mathrm{C}$ NMR (125 MHz, acetone- $d_{6}$ ): see Tables 1 and 2 .

4 $\alpha$-Hydroxy-7-oxo-18-norabieta-8,11,13-trien- $4 \alpha$-ol (4a): Gum; $[\alpha]_{\mathrm{D}}^{25}+5.1$ ( c 0.50, MeOH); UV (MeOH) $\lambda_{\max }$ (log $\epsilon) 231$ (3.73), 281 (3.62) nm; IR (neat) $v_{\max } 3335,1654$, 1596, $1503 \mathrm{~cm}^{-1}$; HREIMS m/z 302.1881 [M] ${ }^{+}$(calcd. for $\mathrm{C}_{19} \mathrm{H}_{26} \mathrm{O}_{3}$ 302.1876); ${ }^{1} \mathrm{H}\left(500 \mathrm{MHz}, \mathrm{CDCl}_{3}\right)$ and ${ }^{13} \mathrm{C}$ NMR (125 MHz, $\left.\mathrm{CDCl}_{3}\right)$ : see Tables 1 and 2.

15,16-Dehydrosugiol (5): Colorless solid; $[\alpha]_{\mathrm{D}}^{25}+8.2$ (c 0.4, MeOH); UV (MeOH) $\lambda_{\max }(\log \epsilon) 235$ (3.99), 280 (3.83) nm; IR (KBr) $v_{\max } 3099,1642,1581,1500,1491$, $898,870 \mathrm{~cm}^{-1}$; HREIMS $\mathrm{m} / z 298.1927$ [M] $^{+}$(calcd. for $\left.\mathrm{C}_{20} \mathrm{H}_{26} \mathrm{O}_{2} 298.1934\right) ;{ }^{1} \mathrm{H}\left(500 \mathrm{MHz}, \mathrm{CDCl}_{3}\right)$ and ${ }^{13} \mathrm{C}$ NMR (125 MHz, CDCl $1_{3}$ ): see Tables 1 and 2.

7-Methoxy-6,7-secoabieta-8,11,13-triene-6,12-diol (6): Colorless solid; $[\alpha]_{\mathrm{D}}^{25}-1.2($ c $0.19, \mathrm{MeOH}) ; \mathrm{UV}$ $(\mathrm{MeOH}) \lambda_{\max }(\log \epsilon) 231$ (3.57), 281 (3.08) nm; IR (KBr) $v_{\max } 3368,1614,1582,1485,1442 \mathrm{~cm}^{-1}$; HREIMS $\mathrm{m} / \mathrm{z} 334.2503$ [M] $^{+}$(calcd. for $\mathrm{C}_{21} \mathrm{H}_{34} \mathrm{O}_{3}$ 334.2509); ${ }^{1} \mathrm{H}\left(500 \mathrm{MHz}, \mathrm{CDCl}_{3}\right)$ and ${ }^{13} \mathrm{C} \mathrm{NMR}$ $\left(125 \mathrm{MHz}, \mathrm{CDCl}_{3}\right)$ : see Tables 1 and 2.

$7 \alpha$-Acetoxyabieta-8,12-diene-11,14-dione (7): Yellowish solid; $[\alpha]_{\mathrm{D}}^{25}-23.7$ ( c $\left.0.2, \mathrm{MeOH}\right)$; UV $(\mathrm{MeOH})$ $\lambda_{\max }(\log \epsilon) 257$ (3.92) nm; IR (KBr) $v_{\max } 1731,1650$, 1603, $1461 \mathrm{~cm}^{-1}$; HREIMS $\mathrm{m} / z 358.2151 \mathrm{MM}^{+}$(calcd. for $\mathrm{C}_{22} \mathrm{H}_{30} \mathrm{O}_{4}$ 358.2145); ${ }^{1} \mathrm{H}\left(500 \mathrm{MHz}, \mathrm{CDCl}_{3}\right)$ and ${ }^{13} \mathrm{C}$ NMR (125 MHz, $\mathrm{CDCl}_{3}$ ): see Tables 1 and 2.
$7 \alpha$-Butyloxyethyloxyabieta-8,12-diene-11,14-dione (8): Yellowish solid; $[\alpha]_{\mathrm{D}}^{25}-10.5$ (c 0.4, MeOH); UV $(\mathrm{MeOH}) \lambda_{\max }(\log \epsilon) 256(3.60) \mathrm{nm} ; \mathrm{IR}(\mathrm{KBr}) v_{\max }$ 1652, 1600, $1462 \mathrm{~cm}^{-1}$; HREIMS $\mathrm{m} / z 416.2927[\mathrm{M}]^{+}$ (calcd. for $\left.\mathrm{C}_{26} \mathrm{H}_{40} \mathrm{O}_{4} 416.2928\right) ;{ }^{1} \mathrm{H}\left(500 \mathrm{MHz}, \mathrm{CDCl}_{3}\right.$ ) and ${ }^{13} \mathrm{C}$ NMR (125 MHz, $\mathrm{CDCl}_{3}$ ): see Tables 1 and 2.

\subsection{Anti-lymphangiogenic assay}

The methods for cell culture, cell growth, tube formation, and cytotoxicity of human lymphatic endothelial cells were the same as our previous work [23].

\section{Results and discussion}

Compounds 1 and 2 were separable abietane-type diterpenoids with almost identical physical data (appearance, UV, IR, optical rotation) and spectroscopic properties including ${ }^{1} \mathrm{H}$ (Table 1), ${ }^{13} \mathrm{C}$ NMR spectra (Table 2), and HREIMS. They were obtained as gum with positive optical activity, and were assigned the same molecular formula as $\mathrm{C}_{20} \mathrm{H}_{30} \mathrm{O}_{3}$ through analysis of the molecular ion $[\mathrm{M}]^{+}$at $\mathrm{m} / \mathrm{z}$ 318.2197 (calcd. for $\mathrm{C}_{20} \mathrm{H}_{30} \mathrm{O}_{3}$ 318.2195) in the HREIMS, which indicated six degrees of unsaturation. The following gross structure determination took compound 1 as an example, and determined the relative configuration of compounds 1 and 2 by NOESY interpretation and coupling constant. The IR spectrum of compound 1 showed absorptions at 33651617,1582 , and $1578 \mathrm{~cm}^{-1}$, indicating the 


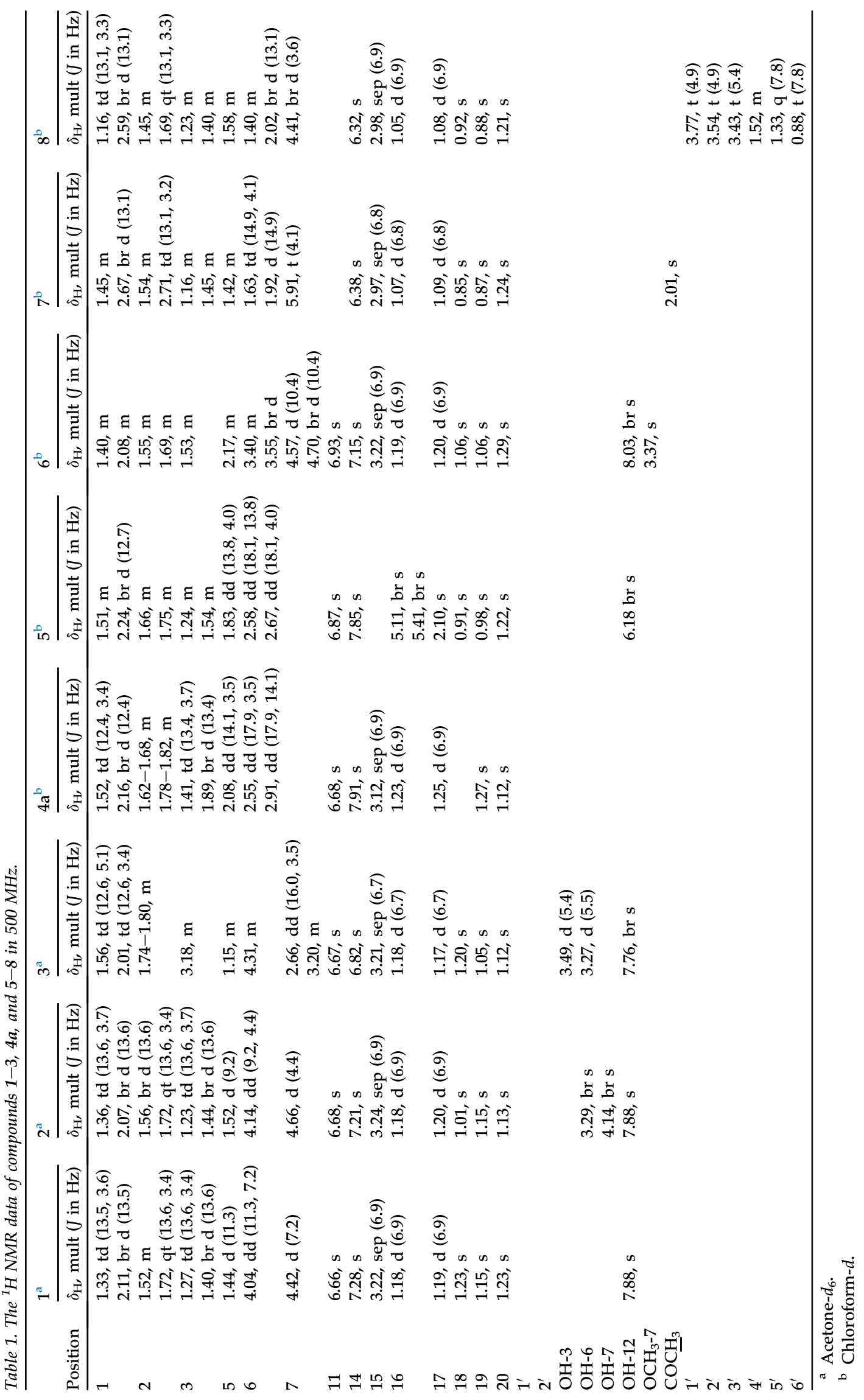


Table 2. The ${ }^{13} C$ NMR data of compounds 1-3, 4a, and 5-8 in $125 \mathrm{MHz}$

\begin{tabular}{|c|c|c|c|c|c|c|c|c|}
\hline \multirow[b]{2}{*}{ Position } & $1^{\mathrm{a}}$ & $2^{a}$ & $3^{\mathrm{a}}$ & $4 a^{b}$ & $5^{b}$ & $6^{\mathrm{b}}$ & $7^{\mathrm{b}}$ & $8^{b}$ \\
\hline & \multicolumn{8}{|c|}{$\delta_{\mathrm{C}}$} \\
\hline 1 & 40.2 & 40.1 & 37.8 & 37.1 & 37.8 & 40.8 & 35.9 & 35.7 \\
\hline 2 & 19.8 & 19.9 & 28.6 & 20.1 & 18.9 & 20.2 & 18.6 & 18.9 \\
\hline 3 & 44.5 & 44.0 & 78.9 & 42.5 & 41.3 & 42.5 & 41.1 & 41.0 \\
\hline 4 & 34.3 & 34.3 & 40.4 & 71.6 & 33.3 & 34.4 & 33.0 & 33.1 \\
\hline 5 & 54.3 & 53.0 & 57.9 & 51.1 & 49.3 & 54.2 & 46.1 & 45.3 \\
\hline 6 & 75.0 & 70.6 & 67.9 & 34.8 & 36.0 & 62.2 & 24.7 & 23.0 \\
\hline 7 & 79.0 & 70.3 & 40.6 & 197.9 & 198.4 & 74.4 & 64.7 & 70.0 \\
\hline 8 & 129.2 & 128.5 & 126.2 & 124.6 & 124.2 & 127.6 & 137.7 & 139.8 \\
\hline 9 & 148.2 & 148.2 & 148.5 & 155.3 & 157.0 & 148.7 & 153.9 & 151.8 \\
\hline 10 & 40.6 & 39.3 & 38.6 & 38.6 & 38.1 & 43.6 & 39.1 & 39.1 \\
\hline 11 & 110.5 & 110.2 & 110.1 & 110.1 & 110.3 & 115.3 & 187.8 & 188.3 \\
\hline 12 & 154.4 & 154.6 & 153.4 & 158.3 & 157.9 & 154.4 & 132.0 & 131.6 \\
\hline 13 & 133.1 & 132.7 & 132.2 & 132.9 & 127.0 & 132.0 & 153.5 & 153.6 \\
\hline 14 & 126.4 & 126.9 & 127.0 & 126.7 & 127.8 & 132.9 & 186.0 & 187.1 \\
\hline 15 & 27.6 & 27.6 & 27.4 & 26.8 & 141.2 & 27.4 & 26.4 & 26.4 \\
\hline 16 & 22.9 & 22.9 & 23.0 & 23.3 & 116.2 & 22.7 & 21.2 & 21.2 \\
\hline 17 & 23.0 & 23.0 & 23.0 & 22.4 & 24.2 & 22.9 & 21.3 & 21.3 \\
\hline 18 & 36.8 & 35.7 & 29.9 & & 32.6 & 35.3 & 33.0 & 33.0 \\
\hline 19 & 22.5 & 22.6 & 16.9 & 22.6 & 21.4 & 24.0 & 21.6 & 21.9 \\
\hline 20 & 26.9 & 24.7 & 23.0 & 23.0 & 23.2 & 23.4 & 18.8 & 18.6 \\
\hline $\mathrm{COCH}_{3}$ & & & & & & & 169.6 & \\
\hline$\overline{\mathrm{CO}} \mathrm{CH}_{3}$ & & & & & & & 21.1 & \\
\hline $\mathrm{OC} \overline{\mathrm{H}}_{3}-7$ & & & & & & 58.0 & & \\
\hline $1^{\prime}$ & & & & & & & & 69.4 \\
\hline $2^{\prime}$ & & & & & & & & 70.1 \\
\hline $3^{\prime}$ & & & & & & & & 71.0 \\
\hline $4^{\prime}$ & & & & & & & & 31.8 \\
\hline $5^{\prime}$ & & & & & & & & 19.3 \\
\hline $6^{\prime}$ & & & & & & & & 14.0 \\
\hline
\end{tabular}

presence of a hydroxy group and an aromatic ring, respectively. The maximum absorption of the UV spectrum at 235 and $280 \mathrm{~nm}$ also suggested the existence of an aromatic ring. The ${ }^{1} \mathrm{H}$ NMR spectrum in combination with $\mathrm{HMQC}$ spectrum of compound 1 showed two aromatic proton signals at $\delta_{\mathrm{H}} 6.66(1 \mathrm{H}$, $\mathrm{s}, \mathrm{H}-11), 7.28(1 \mathrm{H}, \mathrm{s}, \mathrm{H}-14)$, a set of isopropyl group at $\delta_{\mathrm{H}} 1.18\left(3 \mathrm{H}, \mathrm{d}, J=6.9 \mathrm{~Hz}, \mathrm{H}_{3}-16\right), 1.19(3 \mathrm{H}, \mathrm{d}$, $\left.J=6.9 \mathrm{~Hz}, \mathrm{H}_{3}-17\right), 3.22(1 \mathrm{H}$, sep, $J=6.9 \mathrm{~Hz}, \mathrm{H}-15)$, three methyl groups at $\delta_{\mathrm{H}} 1.15\left(3 \mathrm{H}, \mathrm{s}, \mathrm{H}_{3}-19\right), 1.23$ $\left(3 \mathrm{H}, \mathrm{s}, \mathrm{H}_{3}-18\right), 1.23\left(3 \mathrm{H}, \mathrm{s}, \mathrm{H}_{3}-20\right)$, two oxymethines at $\delta_{\mathrm{H}} 4.04(1 \mathrm{H}, \mathrm{dd}, J=11.3,7.2 \mathrm{~Hz}, \mathrm{H}-6), 4.42(1 \mathrm{H}, \mathrm{d}$, $J=7.2 \mathrm{~Hz}, \mathrm{H}-7)$, and one hydroxy group at $\delta_{\mathrm{H}} 7.88$ $\left(1 \mathrm{H}, \mathrm{s}, \mathrm{OH}-12, \mathrm{D}_{2} \mathrm{O}\right.$ exchangeable) (Table 1). The ${ }^{13} \mathrm{C}$ NMR together with DEPT spectra of compound 1 showed an aromatic ring signals at $\delta_{\mathrm{C}} 110.5(\mathrm{C}-11)$, 126.4 (C-14), 129.2 (C-8), 133.1 (C-13), 148.2 (C-9), 154.4 (C-12); five methyl signals at $\delta_{\mathrm{C}} 22.5$ (C-19), 22.9 (C-16), 23.0 (C-17), 26.9 (C-20), 36.8 (C-18); two oxymethine signals at $\delta_{\mathrm{C}} 75.0(\mathrm{C}-6), 79.0(\mathrm{C}-7)$; three methylene signals at $\delta_{\mathrm{C}} 19.8(\mathrm{C}-2), 40.2(\mathrm{C}-1), 44.5$ (C-3); two methine signals at $\delta_{\mathrm{C}} 27.6$ (C-15), 54.3 (C$5)$; and one nonprotonated carbon signal at $\delta 40.6$
(C-10) (Table 2). On account of unsaturated degree of an aromatic ring was four, indicating the existence of two additional rings to fit the six degrees of unsaturation in 1 . The COSY correlations of $\mathrm{H}_{2}-2$ / $\mathrm{H}_{2}-1$ and $\mathrm{H}_{2}-3 ; \mathrm{H}-6 / \mathrm{H}-5$ and $\mathrm{H}-7$ revealed the existence of two fragments, $\mathrm{H}-1-\mathrm{H}-2-\mathrm{H}-3$ and $\mathrm{H}-5-\mathrm{H}-6-$ H-7 (Fig. 2), respectively. Meanwhile, the isopropyl group was confirmed via cross-peaks of $\mathrm{H}-15 / \mathrm{H}_{3}-16$ and $\mathrm{H}_{3}-17$ in the COSY spectrum (Fig. 2). In the HMBC spectrum, the correlations of $\mathrm{H}-5 / \mathrm{C}-1, \mathrm{C}-3$, C-4, C-6, C-7, C-9, and C-10 verified the existence of a six-six-membered ring, and the correlations of $\mathrm{H}$ $7 / C-8, C-9$, and C-14 elucidated the aromatic ring was attached on C-8/C-9 (Fig. 2). Correlations of H$15 / \mathrm{C}-12, \mathrm{C}-13$, and C-14; $\mathrm{H}_{3}-16 / \mathrm{C}-13$ in the HMBC spectrum indicated that the isopropyl group was connected to $\mathrm{C}-13$, and the hydroxy group was attached on C-12 (Fig. 2). Further HMBC correlations of $\mathrm{H}_{3}-20 / \mathrm{C}-1, \mathrm{C}-9$, and $\mathrm{C}-10$ supported that the methyl group (C-20) was located at C-10 (Fig. 2). Other key correlations of $\mathrm{H}-5 / \mathrm{C}-18$ and C-19; H-18/ C-3, C-4, C-5, and C-19 in the HMBC spectrum confirmed the dimethyl groups of C-18 and C-19 were located at C-4 (Fig. 2). Thus, the plain structures of compounds 1 and 2 were elucidated as $4 \beta, 5,6,7,8,8 \alpha, 9,10$-octahydro-4 $\beta, 8,8$-trimethyl-2-(1methylethyl)-3,9,10-phenanthrentriol, the same as that of $6 \beta, 7 \alpha$-dihydroxyferruginol [24]. All spectroscopic data of individual compounds 1 and 2 indicated they were stereoisomers with the stereochemical centers at C-6/C-7. The relative configuration of $\mathrm{H}-5, \mathrm{H}-6$, and $\mathrm{H}-7$ were confirmed by the coupling constant between $\mathrm{H}-5 / \mathrm{H}-6$ and $\mathrm{H}-6 /$ $\mathrm{H}-7$ to be $\mathrm{H}_{\mathrm{ax}}-5 \alpha, \mathrm{H}_{\mathrm{ax}}-6 \beta$, and $\mathrm{H}_{\mathrm{ax}}-7 \beta$ in compound 1 $\left(J_{\mathrm{H}-5 / \mathrm{H}-6}=11.3 \mathrm{~Hz}\right.$ and $\left.J_{\mathrm{H}-6 / \mathrm{H}-7}=7.2 \mathrm{~Hz}\right) ; \mathrm{H}_{\mathrm{ax}}-5 \alpha$, $\mathrm{H}_{\mathrm{ax}}-6 \beta$, and $\mathrm{H}_{\mathrm{eq}}-7 \beta$ in compound $2\left(J_{\mathrm{H}-5 / \mathrm{H}-6}=9.2 \mathrm{~Hz}\right.$ and $J_{\mathrm{H}-6 / \mathrm{H}-7}=4.4 \mathrm{~Hz}$ ), respectively. Meanwhile, the NOESY correlation between $\mathrm{H}-6 / \mathrm{H}-7$ in compound 1, $\mathrm{H}-5 / \mathrm{H}-7$ in compound 2, and the short of NOESY correlation between $\mathrm{H}-5 / \mathrm{H}-6$ in both compounds 1 and 2 can proved the above concept (Fig. 3). The remaining chiral center of C-4 and C-10 in all compounds 1 and 2 were assigned to be $\mathrm{H}_{\mathrm{eq}}-18 \alpha$, $\mathrm{H}_{\mathrm{ax}}-19 \beta$, and $\mathrm{H}_{\mathrm{ax}}-20 \beta$ based on the NOESY correlations of $\mathrm{H}-5 / \mathrm{H}_{3}-18$ and $\mathrm{H}_{3}-19 / \mathrm{H}_{3}-20$ (Fig. 3). Based on above assignments, the entire structures of compounds 1 and 2 were deduced to be as shown. Compounds 1 and 2 were previously unreported, and they were named as $6 \alpha, 7 \beta$-dihydroxyferruginol and $6 \alpha, 7 \alpha$-dihydroxyferruginol, respectively.

Compound 3 was isolated as a gum with positive specific optical rotation, and displayed a molecular ion at $\mathrm{m} / z$ 318.2200 $[\mathrm{M}]^{+}$(calcd. 318.2189 for $\mathrm{C}_{20} \mathrm{H}_{30} \mathrm{O}_{3}$ ) by HREIMS. The UV spectrum exhibited bands at 218 and $280 \mathrm{~nm}$, indicating the presence of 


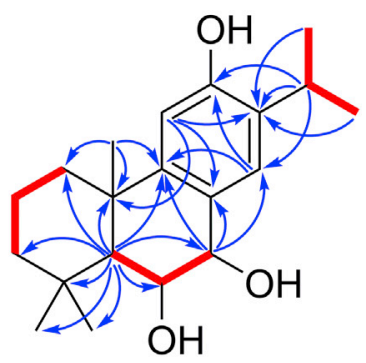

1

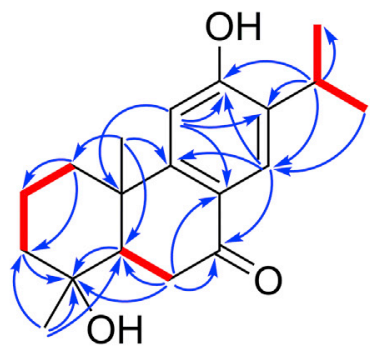

4

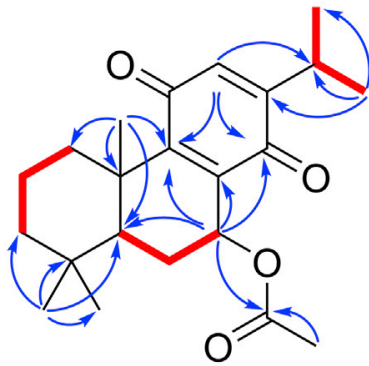

7

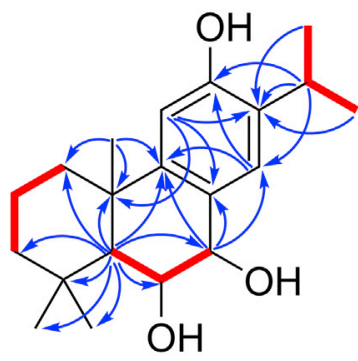

2

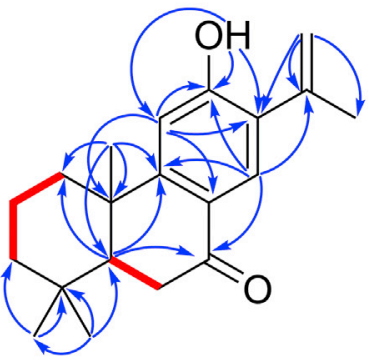

5

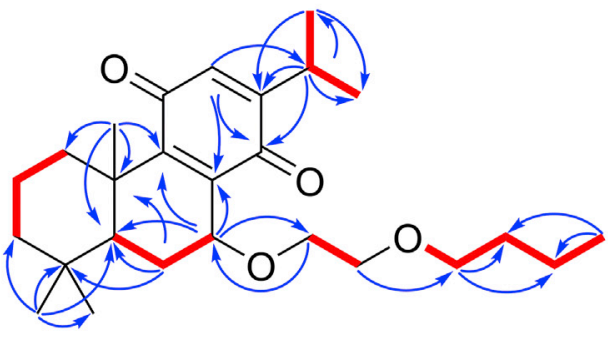

8
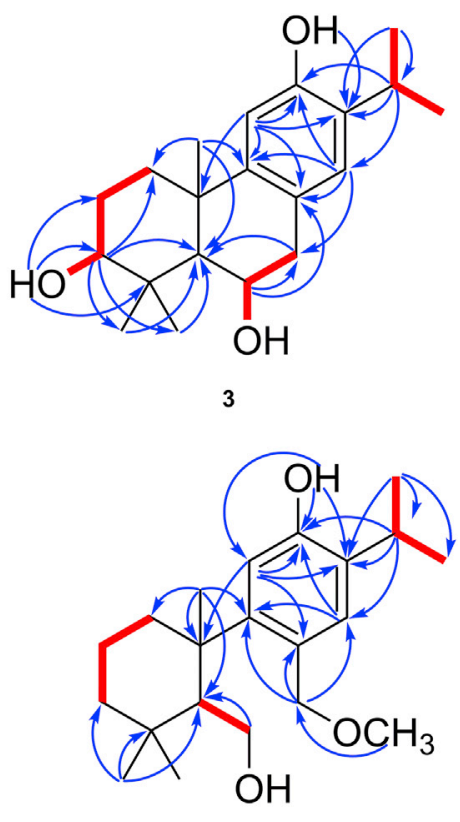

6

Fig. 2. Key COSY (-) and HMBC $(\longrightarrow)$ correlations of 1-3, 4a, and 5-8.

an aromatic ring. The IR spectrum showed the absorption bands at $3368 \mathrm{~cm}^{-1}$ (hydroxy group), 1616, and $1505 \mathrm{~cm}^{-1}$ (aromatic ring). The NMR data of compound 3 were almost compatible with those of compound 1 except that the hydroxy group at C-7 in compound 1 was shifted to $\mathrm{C}-3$ in compound 3 (Tables 1 and 2). The hydroxy group $\left(\delta_{\mathrm{H}} 3.49, \mathrm{~d}\right.$, $J=5.4 \mathrm{~Hz}, \mathrm{OH}-3, \mathrm{D}_{2} \mathrm{O}$ exchangeable) was located at C-3 based on the HMBC correlations of $\delta_{\mathrm{H}} 3.18(1 \mathrm{H}$, $\mathrm{m}, \mathrm{H}-3) / \delta_{\mathrm{C}} 37.8$ (C-1), 57.9 (C-5), 29.9 (C-18), 16.9 (C19) and $\delta_{\mathrm{H}} 3.49(\mathrm{OH}-3) / \delta_{\mathrm{C}} 28.6(\mathrm{C}-2), 78.9(\mathrm{C}-3)$, and 40.4 (C-4) (Fig. 2). The NOESY correlations from $\delta_{\mathrm{H}}$ $1.12\left(3 \mathrm{H}, \mathrm{s}, \mathrm{H}_{\mathrm{ax}}-20 \beta\right)$ to $\delta_{\mathrm{H}} 2.01(1 \mathrm{H}, \mathrm{td}, J=12.6$, $\left.3.4 \mathrm{~Hz}, \mathrm{H}_{\mathrm{eq}}-1 \mathrm{a}\right), 4.31\left(1 \mathrm{H}, \mathrm{m}, \mathrm{H}_{\mathrm{ax}}-6 \beta\right)$, and $1.05(3 \mathrm{H}, \mathrm{s}$, $\left.\mathrm{H}_{\mathrm{ax}}-19 \beta\right)$ indicated $\mathrm{H}-6, \mathrm{H}-19$, and $\mathrm{H}-20$ were in $\beta-$ axial position, and $\mathrm{H}-1 \mathrm{a}$ was in $\beta$-equatorial position (Fig. 3). Furthermore, H-3 occupied $\alpha$-axial position based on the NOESY correlations from H-3 to $\delta_{\mathrm{H}}$ $1.56\left(1 \mathrm{H}, \mathrm{td}, J=12.6,5.1 \mathrm{~Hz}, \mathrm{H}_{\mathrm{ax}}-1 \mathrm{~b}\right), 1.15(1 \mathrm{H}, \mathrm{m}$, $\left.\mathrm{H}_{\mathrm{ax}}-5 \alpha\right)$, and $1.20\left(3 \mathrm{H}, \mathrm{s}, \mathrm{H}_{\mathrm{eq}}-18 \alpha\right)$ (Fig. 3), and without NOESY correlation between $\mathrm{H}-3 / \mathrm{H}_{\mathrm{ax}}-19 \beta$. Accordingly, the structure of compound 3 was well determined, and it was named $6 \alpha$-hydroxyhinokiol. Compound 4 a was assigned the molecular formula $\mathrm{C}_{19} \mathrm{H}_{26} \mathrm{O}_{3}$ through analysis of its molecular ion $[\mathrm{M}]^{+}$ at $\mathrm{m} / \mathrm{z} 302.1881$ (calcd. 302.1876), indicating seven degree of unsaturation. The existence of an aromatic ring was evidenced based on its UV $\lambda_{\max }$ at 231 and $281 \mathrm{~nm}$ and IR absorption bands at 1596, 1503, and $1461 \mathrm{~cm}^{-1}$. The IR spectrum also revealed the hydroxy group (3335 $\mathrm{cm}^{-1}$ ) and conjugated carbonyl group $\left(1654 \mathrm{~cm}^{-1}\right)$. The NMR spectroscopic data of compound 4 a displayed similarity to those of sugiol (4b) [25] except that the methyl group (C-18) of $4 b$ was replaced by a hydroxy group in compound 4 a with down field shift of C-4 to $\delta_{C}$ 71.6. (Tables 1 and 2 ). The presence of the C-7 carbonyl group was indicated by the HMBC correlations from $\delta_{\mathrm{H}} 2.08(1 \mathrm{H}, \mathrm{dd}$, $J=14.1,3.5 \mathrm{~Hz}, \mathrm{H}-5), 2.55$ (1H, dd, $J=17.9,3.5 \mathrm{~Hz}, \mathrm{H}-$ 6b), $2.91(1 \mathrm{H}, \mathrm{dd}, J=17.9,14.1 \mathrm{~Hz}, \mathrm{H}-6 \mathrm{a})$ and $7.91(1 \mathrm{H}$, 


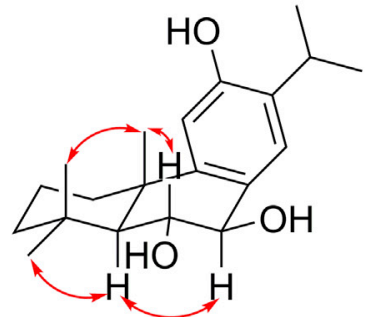

1

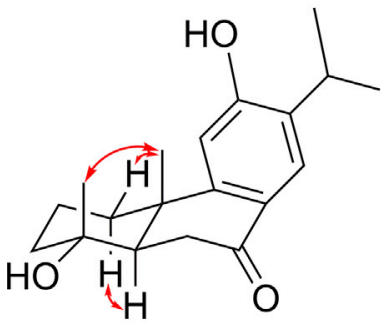

4

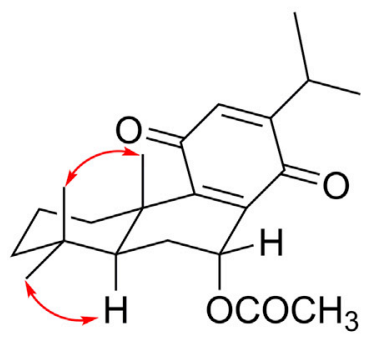

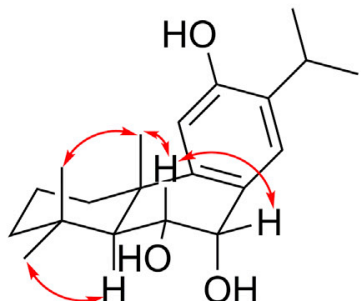

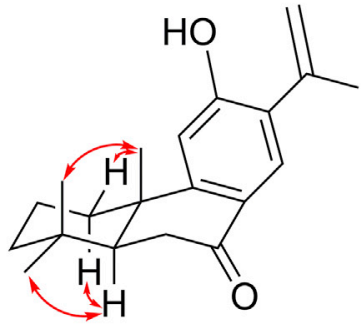

5

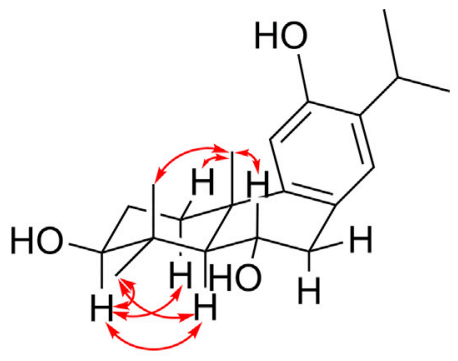

3

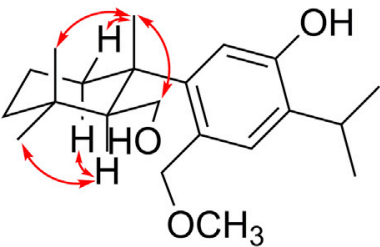

6

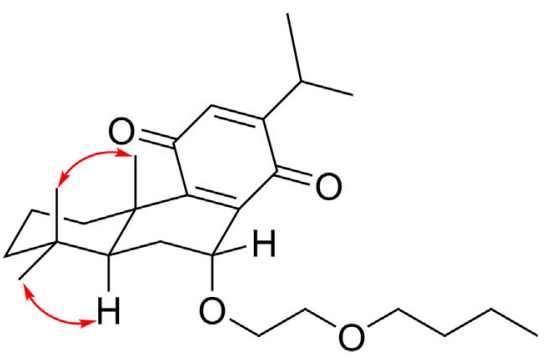

8

Fig. 3. Key NOESY $(\leftrightarrow)$ correlations of 1-3, 4a, and 5-8.

s, H-14) to C-7 (Fig. 2). The HMBC correlations from $\delta_{\mathrm{H}} 1.41(1 \mathrm{H}, \mathrm{td}, J=13.4,3.7 \mathrm{~Hz}, \mathrm{H}-3 \mathrm{~b}), 2.08(\mathrm{H}-5), 2.55$ $(\mathrm{H}-6)$, and $1.27(3 \mathrm{H}, \mathrm{s}, \mathrm{H}-19)$ to $\delta_{\mathrm{C}} 71.6(\mathrm{C}-4)$ confirmed a hydroxy group was attached at C-4 (Fig. 2). The NOESY correlations of $\mathrm{H}_{\mathrm{ax}}-20(\delta 1.12) / \mathrm{H}_{\mathrm{eq}}-1 \mathrm{a}(\delta 2.16)$ and $\mathrm{H}_{\mathrm{ax}}-19$ ( $\left.\delta 1.27\right) ; \mathrm{H}_{\mathrm{ax}}-5 / \mathrm{H}_{\mathrm{ax}}-1 \mathrm{~b}$ (Fig. 3), corroborated that $\mathrm{H}-19$ and $\mathrm{H}-20$ were in $\beta$-position, while $\mathrm{OH}-4$ and $\mathrm{H}-5$ were in $\alpha$-position. Consequently, compound $4 \mathrm{a}$ was identified as $4 \alpha$-hydroxy-7-oxo18-norabieta-8,11,13-triene- $4 \alpha$-ol.

The physical data and spectroscopic properties of compound 5 were almost identical with that of sugiol (4b), except the isopropyl group in compound $4 b$ was replaced by the isopropenyl in compound 5 . The methyl group of 5 at $\delta_{\mathrm{H}} 0.91\left(3 \mathrm{H}, \mathrm{s}, \mathrm{H}_{3}-18\right)$ was attached on C-4 $\left(\delta_{\mathrm{C}} 33.3\right)$ based on the HMBC correlations of $\delta_{\mathrm{H}}$ $0.91\left(3 \mathrm{H}, \mathrm{s}, \mathrm{H}_{3}-18\right) / \delta_{\mathrm{C}} 33.3(\mathrm{C}-4), 49.3(\mathrm{C}-5)$, and $21.4(\mathrm{C}-$ 19) (Fig. 2). Regarding the compound 5 , the terminal alkene $\left[v_{\max } 898,870 \mathrm{~cm}^{-1}\right.$ in IR spectrum $]\left[\delta_{\mathrm{H}} 5.11(1 \mathrm{H}\right.$, br s, H-16b) and $5.41\left(1 \mathrm{H}\right.$, br s, H-16a); $\delta_{\mathrm{C}} 116.2(\mathrm{C}-16)$ and 141.2 (C-15)] was assigned for C-15 and C-16 based on the HMBC correlations of $\mathrm{H}_{2}-16 / C-14, C-15$, C-17 and $\mathrm{H}-14 / \mathrm{C}-15$ (Fig. 2). The relative configuration of compound 5 was identical to those of compound $4 b$ based on their similar NOESY spectroscopic data (Fig. 3). The structure of compound 5 were thus established as shown, and was named 15,16dehydrosugiol.

Compound 6 was obtained as a colorless solid, and its molecular formula was established as $\mathrm{C}_{21} \mathrm{H}_{34} \mathrm{O}_{3}$ by HREIMS with a molecular ion $[\mathrm{M}]^{+}$at $\mathrm{m} / z 334.2503$ (calcd. 334.2509), which was consistent with five indices of hydrogen deficiency (IHDs). The IR spectrum showed a hydroxy group $\left(3368 \mathrm{~cm}^{-1}\right)$ and an aromatic ring $\left(1614,1582,1485 \mathrm{~cm}^{-1}\right)$, which was also reflected in its UV absorbance maxima at 231 and $281 \mathrm{~nm}$. The ${ }^{13} \mathrm{C}$ NMR and DEPT data of 6 were very similar to those of 1 with the exception that resonances associated with the oxymethines (C-6 and C-7) in 1 were changed into two oxymethylene groups $[\delta$ 
62.2 (C-6) and 74.4 (C-7)] in 6 (Table 2). Besides, the NMR spectra of 6 showed an additional methoxy group $\left[\delta_{\mathrm{H}} 3.37\left(3 \mathrm{H}, \mathrm{s},-\mathrm{OCH}_{3}\right) ; \delta_{\mathrm{C}} 58.0(-\mathrm{OCH} 3)\right]$ (Tables 1 and 2). These results, together with the five IHDs, indicated that 6 was proposed being 6,7secoabietane diterpene. The ${ }^{1} \mathrm{H}-{ }^{1} \mathrm{H}$ COSY plot between $\delta_{\mathrm{H}} 2.17(1 \mathrm{H}, \mathrm{m}, \mathrm{H}-5)$ and $\delta_{\mathrm{H}} 3.40(1 \mathrm{H}, \mathrm{m}, \mathrm{H}-6 \mathrm{~b}) /$ $3.55(1 \mathrm{H}, \mathrm{br} \mathrm{s}, \mathrm{H}-6 \mathrm{a})$ (Fig. 2), as well as the intense HMBC correlation from $\mathrm{H}_{2}-6$ to $\delta_{C} 54.2$ (C-5) (Fig. 2), indicating the connectivity between $\mathrm{C}-5$ and $\mathrm{C}-6$. The connection between C-7 and C-8 was confirmed by the HMBC correlations from $\delta_{\mathrm{H}} 4.57(1 \mathrm{H}$, br $\mathrm{d}$, $J=10.4 \mathrm{~Hz}, \mathrm{H}-7 \mathrm{~b}) / 4.70(1 \mathrm{H}, \mathrm{d}, J=10.4 \mathrm{~Hz}, \mathrm{H}-7 \mathrm{a})$ to $\delta_{\mathrm{C}}$ 127.6 (C-8), 132.9 (C-14), and 148.7 (C-9) (Fig. 2). The methoxy group $\left(3.37, \mathrm{~s},-\mathrm{OCH}_{3}\right)$ located at $\mathrm{C}-7$ was demonstrated by the $\mathrm{HMBC}$ correlation from $-\mathrm{OCH}_{3}$ to C-7 (Fig. 2). The relative configuration of 6 was established by interpretation of its NOESY spectrum, in which the cross-peak of $\delta_{\mathrm{H}} 1.29\left(3 \mathrm{H}, \mathrm{s}, \mathrm{H}_{\mathrm{ax}}-20 \beta\right) / \delta_{\mathrm{H}}$ 3.40, 3.55 (each $\left.1 \mathrm{H}, \mathrm{H}_{\mathrm{eq}}-6 \beta\right)$ and $1.06\left(3 \mathrm{H}, \mathrm{s}, \mathrm{H}_{\mathrm{ax}}-19 \beta\right)$ (Fig. 3), and the absence of NOESY correlation between $\delta_{\mathrm{H}} 2.17\left(1 \mathrm{H}, \mathrm{m}, \mathrm{H}_{\mathrm{ax}}-5 \alpha\right) / \delta_{\mathrm{H}} 1.29\left(3 \mathrm{H}, \mathrm{s}, \mathrm{H}_{\mathrm{ax}}-20 \beta\right)$, indicating $\mathrm{H}-6, \mathrm{H}-19$, and $\mathrm{H}-20$ were in $\beta$-orientation, while $\mathrm{H}-5$ was in the opposite site. Therefore, compound 6 was identified as shown, and was named 7methoxy-6,7-secoabieta-8,11,13-triene-6,12-diol.

Compound 7 was a yellowish solid with molecular formula $\mathrm{C}_{22} \mathrm{H}_{30} \mathrm{O}_{4}$ determined from HREIMS with a molecular ion [M] $]^{+}$at $m / z 358.2151$ (calcd. 358.2145). Maximal UV absorption at $257 \mathrm{~nm}$, IR absorptions at 1731, 1650, and $1603 \mathrm{~cm}^{-1}$, as well as the ${ }^{13} \mathrm{C}$ NMR peaks (Table 2) at $\delta 132.0$ (C-12), 137.7 (C-8), 153.5 (C13), 153.9 (C-9), 186.0 (C-14), and 187.8 (C-11) suggested the existence of $p$-benzoquinone residue [26]. Typical ${ }^{1} \mathrm{H}$ NMR spectrum (Table 1 ) of an isopropyl signals at $\delta 1.07(3 \mathrm{H}, \mathrm{d}, J=6.8 \mathrm{~Hz}, \mathrm{H}-16), 1.09(3 \mathrm{H}$, $J=6.8 \mathrm{~Hz}, \mathrm{H}-17), 2.97(1 \mathrm{H}$, sep, $J=6.8 \mathrm{~Hz}, \mathrm{H}-15)$ and three singlet methyl signals at $\delta 0.85(3 \mathrm{H}, \mathrm{s}, \mathrm{H}-18)$, $0.87(3 \mathrm{H}, \mathrm{s}, \mathrm{H}-19), 1.24(3 \mathrm{H}, \mathrm{s}, \mathrm{H}-20)$ revealed compound 7 was an abietane diterpene. Based on the above data, compound 7 was almost compatible with the known compound, 12-deoxyroyleanone [26], except that the molecular weight of compound 7 were $58 \mathrm{Da}\left(\mathrm{C}_{2} \mathrm{H}_{2} \mathrm{O}_{2}\right)$ more than that of 12 -deoxyroyleanone, indicating that compound 7 was the acetoxy derivative of 12-deoxyroyleanone. Further HMBC correlations (Fig. 2) from H-7 $\left[\delta_{\mathrm{H}} 5.91(\mathrm{~d}\right.$, $J=4.1 \mathrm{~Hz})]$ to acetoxy group $\left(\delta_{\mathrm{C}} 169.6\right)$ confirmed the acetoxy group was located at C-7. Besides, compound 7 had smaller coupling constant $(J=4.1 \mathrm{~Hz}$ ) between $\mathrm{H}-6 / \mathrm{H}-7$ as well as the NOESY cross-peak (Fig. 3) between $\delta_{\mathrm{H}} 5.91(1 \mathrm{H}, \mathrm{d}, J=4.1 \mathrm{~Hz}$, $\mathrm{H}-7)$ and $\delta_{\mathrm{H}} 1.63\left(1 \mathrm{H}, \mathrm{td}, J=14.9,4.1 \mathrm{~Hz}, \mathrm{H}_{\mathrm{ax}}-6 \beta\right) /$ $1.92\left(1 \mathrm{H}, \mathrm{d}, J=14.9 \mathrm{~Hz}, \mathrm{H}_{\mathrm{eq}}-6 \alpha\right)$ determining that $\mathrm{H}-$ 7 was in $\beta$-equatorial orientation. After fully assignments, compound 7 was named $7 \alpha$-acetoxyabieta-8,12-diene-11,14-dione.

Compound 8 was yield as a yellowish solid and assign the molecular formula $\mathrm{C}_{26} \mathrm{H}_{40} \mathrm{O}_{4}$ through analysis of its HREIMS data. The physical data and NMR spectroscopic spectra of 8 were similar to those of compound 7 (Tables 1 and 2), except for the acetoxy group in 7 was replaced by the ether-linkage alkyl side chain in 8 . The ether-linkage alkyl side chain was confirmed by the COSY correlations of $\delta_{\mathrm{H}} 3.77(2 \mathrm{H}, \mathrm{t}$,

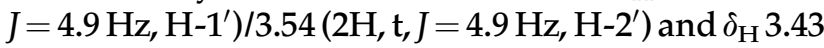
$\left(2 \mathrm{H}, \mathrm{t}, J=5.4 \mathrm{~Hz}, \mathrm{H}-3^{\prime}\right) / 1.52\left(2 \mathrm{H}, \mathrm{m}, \mathrm{H}-4^{\prime}\right) / 1.33(2 \mathrm{H}, \mathrm{q}$, $\left.J=7.8 \mathrm{~Hz}, \mathrm{H}-5^{\prime}\right) / 0.88\left(3 \mathrm{H}, \mathrm{t}, J=7.8 \mathrm{~Hz}, \mathrm{H}-6^{\prime}\right)($ Fig. 2$)$, as well as the HMBC correlations from $\mathrm{H}-2^{\prime}$ to $\delta_{\mathrm{C}} 71.0$ (C$\left.3^{\prime}\right) ; \mathrm{H}-6^{\prime}$ to $\delta_{\mathrm{C}} 31.8\left(\mathrm{C}-4^{\prime}\right)$ and $19.3\left(\mathrm{C}-5^{\prime}\right)$; and $\mathrm{H}-3^{\prime}$ to $\mathrm{C}-4^{\prime}$ (Fig. 2). In the HMBC spectrum, distinctive plot-spot of $\delta_{\mathrm{H}} 4.41(1 \mathrm{H}, \mathrm{br} \mathrm{d}, J=3.6 \mathrm{~Hz}, \mathrm{H}-7)$ to $\delta_{\mathrm{C}} 69.4\left(\mathrm{C}-1^{\prime}\right)$ indicated the alkyl side chain was attached to C-7 (Fig. 2). The small coupling constant between $\mathrm{H}-7$ and $\mathrm{H}-6(\mathrm{br} d, J=3.6 \mathrm{~Hz})$ and the absent of NOESY correlation of $\mathrm{H}_{\mathrm{ax}}-5 \alpha / \mathrm{H}-7$ indicated $\mathrm{H}-7$ was in $\beta$-equatorial position. Accordingly, the entire structure of 8 was established, and it was named $7 \alpha$-butyloxyethyloxyabieta-8,12-diene-11,14-dione.

By comparing the spectroscopic data $\left([\alpha]_{\mathrm{D}}, \mathrm{UV}, \mathrm{IR}\right.$, NMR and MS) of known compounds with the literature data, the known diterpenes were identified to be 6,7-dehydroferruginol (9) [24], 12-hydroxy-6,7-secoabieta-8,11,13-triene-6,7-dial (10) [27], 7 $\alpha$-11-dihydroxy-12-methoxy-8,11,13-abietatriene (11) [28], and 11,14-dihydroxy-8,11,13-abietatrien-7-one (12) [29].

We evaluated anti-lymphangiogenesis potentials of four isolates $(9,10,11$, and 12) present in sufficient amounts in human lymphatic endothelial cells (LECs). Lymphangiogenesis is the process forming new lymphatic vessels emerge from pre-existent vessels or post-capillary venules. Most of lymphangiogenesis occurs in pathologic inflammatory conditions, especially in tumor conditions. Therefore, anti-lymphangiogenesis can stop tumor cells spread in the regional lymph nodes and constitute a therapeutic target for anti-cancer. As shown in Table 3, 12-hydroxy-6,7-secoabieta-8,11,13-triene6,7-dial (10) exhibited the most potent anti-

Table 3. Anti-lymphangiogenic effects of selected compounds.

\begin{tabular}{ll}
\hline Compound & $\mathrm{IC}_{50}(\mu \mathrm{M})$ \\
\hline $\mathbf{9}$ & $47 \pm 1$ \\
$\mathbf{1 0}$ & $18 \pm 2$ \\
$\mathbf{1 1}$ & $33 \pm 2$ \\
$\mathbf{1 2}$ & $36 \pm 2$ \\
Rapamycin & $<10$
\end{tabular}

LECs were treated with the indicated compounds for $48 \mathrm{~h}$, and anti-lymphangiogenic effects were elucidated in a cell growth assay $(n=3)$. Data are expressed as the mean \pm SEM. Rapamycin was used as a positive control. 
Control

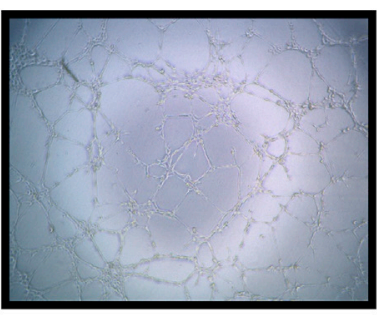

Compound 10

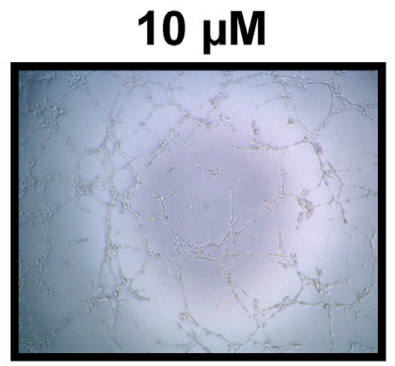

Compound 10 $20 \mu \mathrm{M}$

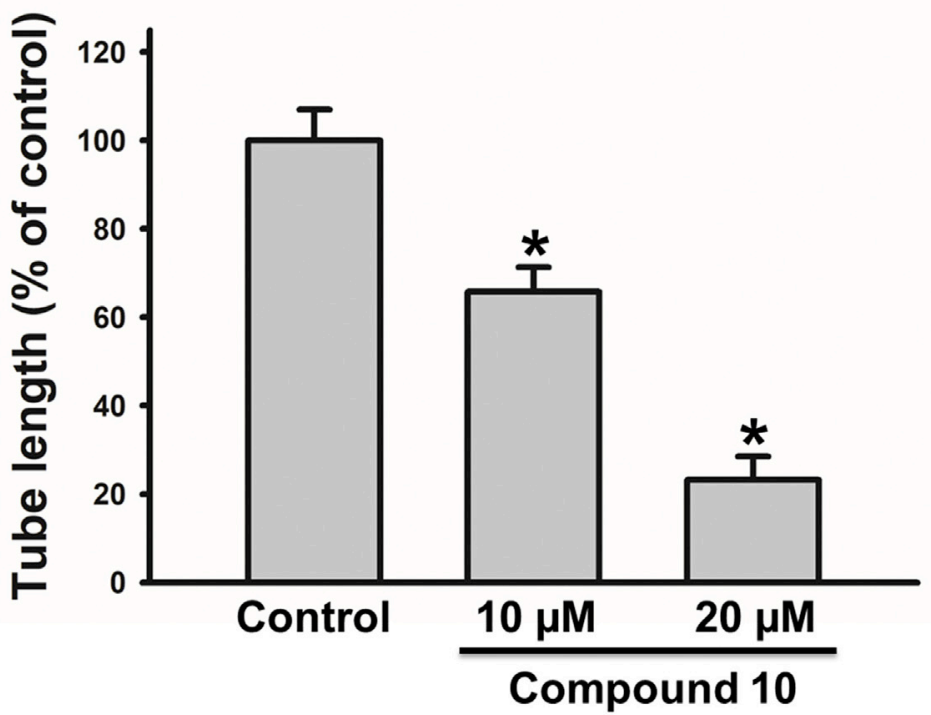

Fig. 4. Effect of compound 10 on LEC tube formation. Cells were treated with compound 10 (10 $\mu M$ and $20 \mu M$, respectively) for 8 h. Capillary-like structure formation was examined by a tube formation assay $(n=5)$. Tube formation of LECs was quantified by measuring the length of tubes using Image software. Data are expressed as the mean \pm SEM. ${ }^{*} p<0.05$ compared with the control (CTL) group.

lymphangiogeneic activity by suppressing LECs growth $\left(\mathrm{IC}_{50}=18 \pm 2 \mu \mathrm{M}\right)$, with rapamycin as the positive control. 6,7-Dehydroferruginol (9), $7 \alpha-11-$ dihydroxy-12-methoxy-8,11,13-abietatriene (11), and 11,14-dihydroxy-8,11,13-abietatrien-7-one (12) illustrated moderate growth-inhibitory effects on LECs with $\mathrm{IC}_{50}$ values of $47 \pm 1,33 \pm 2$, and $36 \pm 2 \mu \mathrm{M}$, respectively. Capillary-like tubules are regarded as an important physiological phenomenon of lymphangiogenesis. For confirming the anti-lymphangiogeic effects of the active compounds, the tube formation assay was performed. As shown in Fig. 4 compound $\mathbf{1 0}$ significantly repressed LECs tube formation in a concentration-dependent manner $\left(\mathrm{IC}_{50}=13.8 \pm 0.6 \mu \mathrm{M}\right)$. In addition, we found that compound $\mathbf{1 0}$ did not induce the significant lactate dehydrogenase (LDH) release in LECs (Suppl. Fig. S1). These findings suggested that compound 10 display the anti-lymphangiogenesis property without any signs of cytotoxicity.

Based on the anti-lymphangiogenesis results, the structure-activity-relationship (SAR) study depicted that the 6,7-seco-abietane type diterpene (compound 10) can considerably increase anti-lymphangiogenic activity. The close $\mathrm{IC}_{50}$ values of $\mathbf{1 1}$ and $\mathbf{1 2}$ depict the substituted might not influence the activity. Among aromatic abietane diterpenes 9, 11, and 12, compounds 11 and 12 showed better LECs growth inhibition activity than compound 9. This finding suggested that the unsaturation between $\mathrm{C} 6-\mathrm{C} 7$ may decrease anti-lymphangiogenic activity.

\section{Declaration of competing interest}

The authors declare no conflicts of interest.

\section{Acknowledgments}

This work was financially supported by China Medical University grant in Taichung, Taiwan (CMU110-Z-08 and CMU109-AWARD-02) and "Chinese Medicine Research Center, China Medical University, Taichung, Taiwan" from The Featured Areas Research Center Program within the 
framework of the Higher Education Sprout Project by the Ministry of Education (MOE) in Taipei, Taiwan (CMRC-CHM-2-1).

\section{Appendix A. Supplementary data}

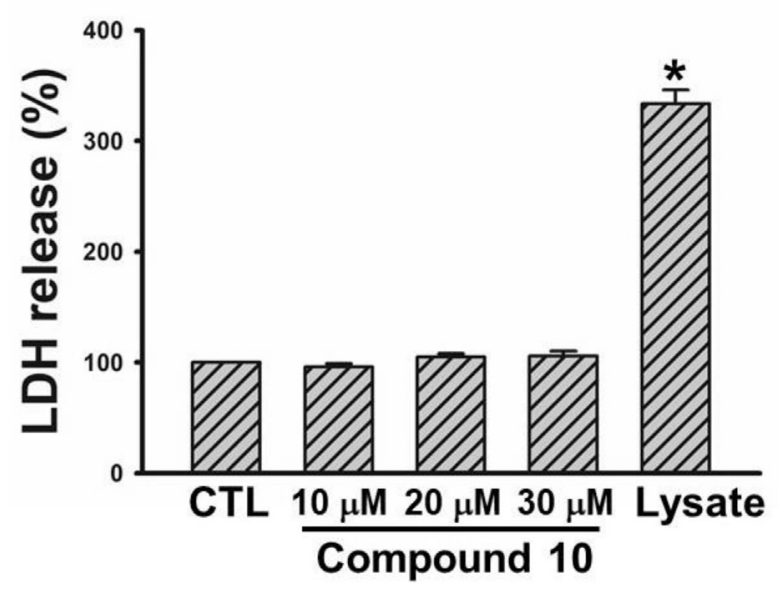

Fig. S1. Effect of compound 10 on cytotoxicity of LECs. Cells were treated with the indicated concentrations of compound 10 for $8 \mathrm{~h}$; then the cytotoxicity was evaluated by the LDH assay $(n=3)$. Data are expressed as the mean \pm SEM. ${ }^{*} p<0.05$ compared with the control (CTL) group.
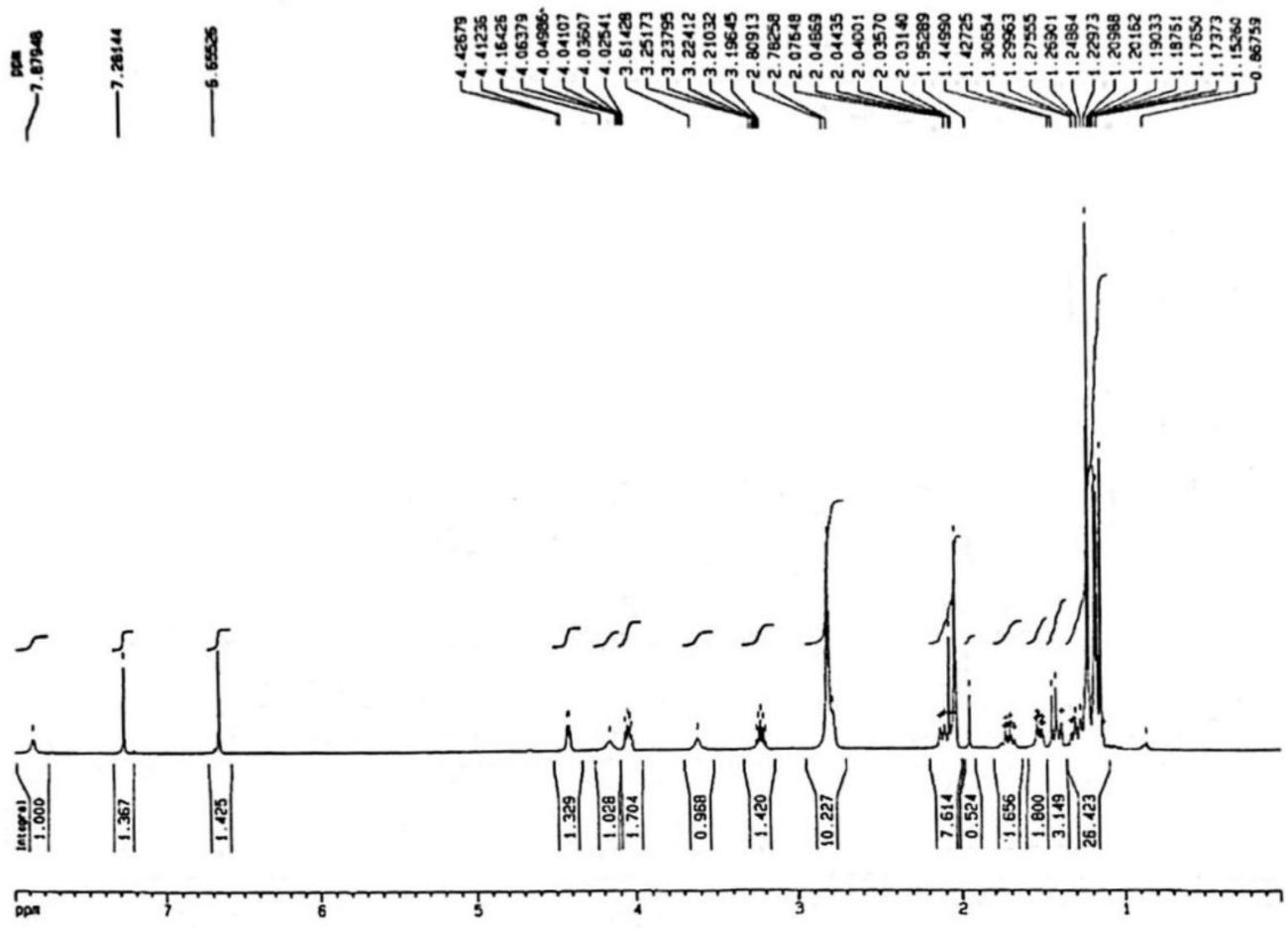

Fig. S2. ${ }^{1} \mathrm{H} N \mathrm{MR}$ spectrum of $6 \alpha, 7 \beta$-dihydroxyferruginol (1) in acetone-d $d_{6}$ at $500 \mathrm{MHz}$. 


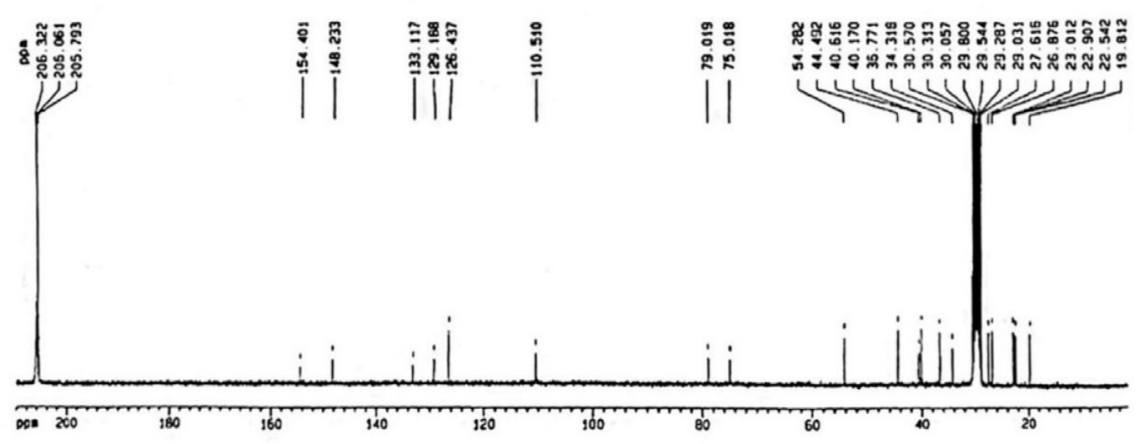

Fig. S3. ${ }^{13} \mathrm{C}$ NMR spectrum of $6 \alpha, 7 \beta$-dihydroxyferruginol (1) in acetone- $d_{6}$ at $125 \mathrm{MHz}$.
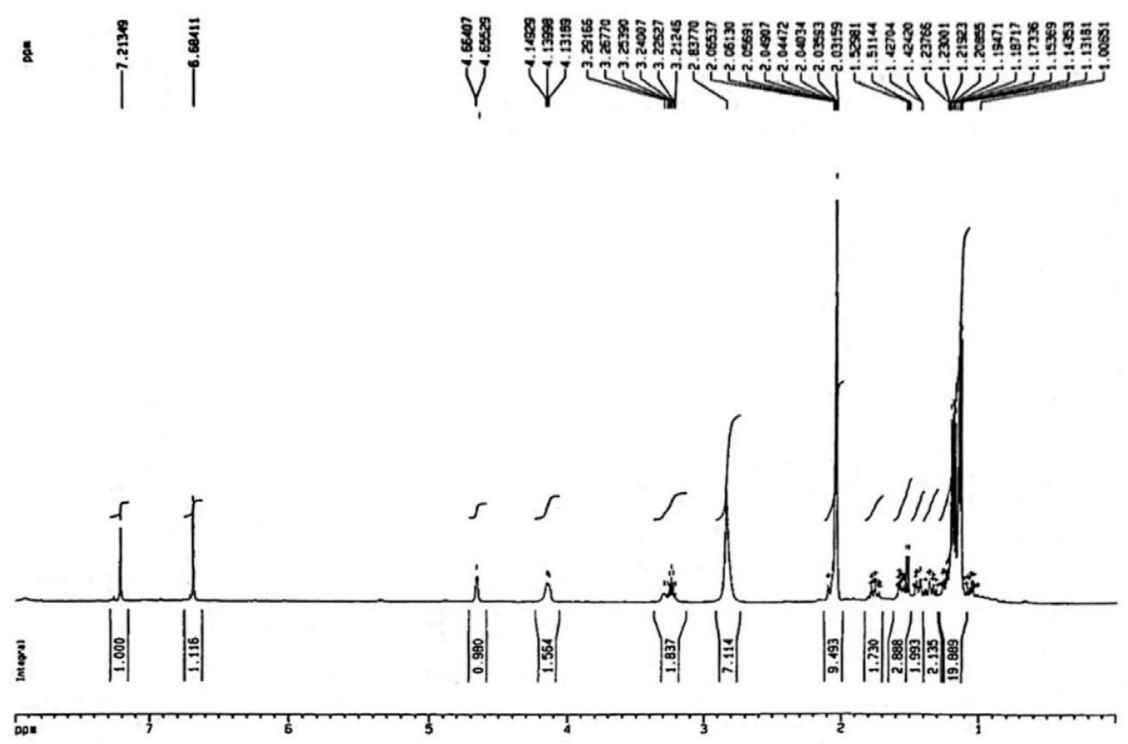

Fig. S4. ${ }^{1} \mathrm{H} N M R$ spectrum of $6 \alpha, 7 \alpha$-dihydroxyferruginol (2) in acetone- $d_{6}$ at $500 \mathrm{MHz}$.

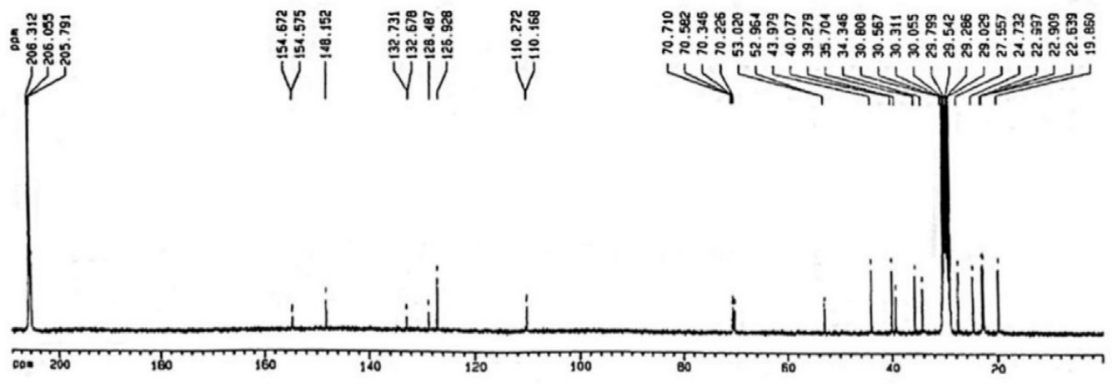

Fig. S5. ${ }^{13} \mathrm{C}$ NMR spectrum of $6 \alpha, 7 \alpha$-dihydroxyferruginol (2) in acetone- $d_{6}$ at $125 \mathrm{MHz}$. 


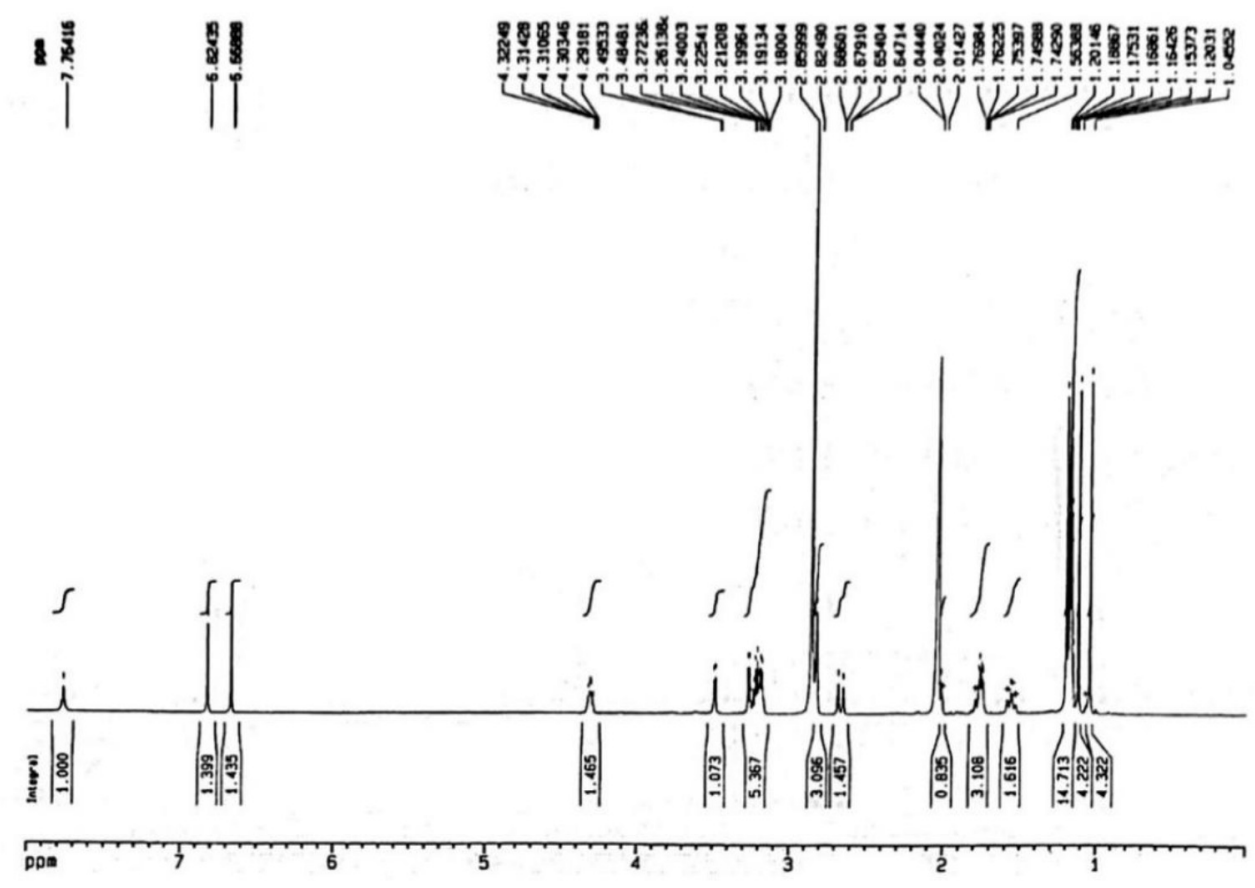

Fig. S6. ${ }^{1} \mathrm{H}$ NMR spectrum of $6 \alpha$-hydroxyhinokiol (3) in acetone- $d_{6}$ at $500 \mathrm{MHz}$.

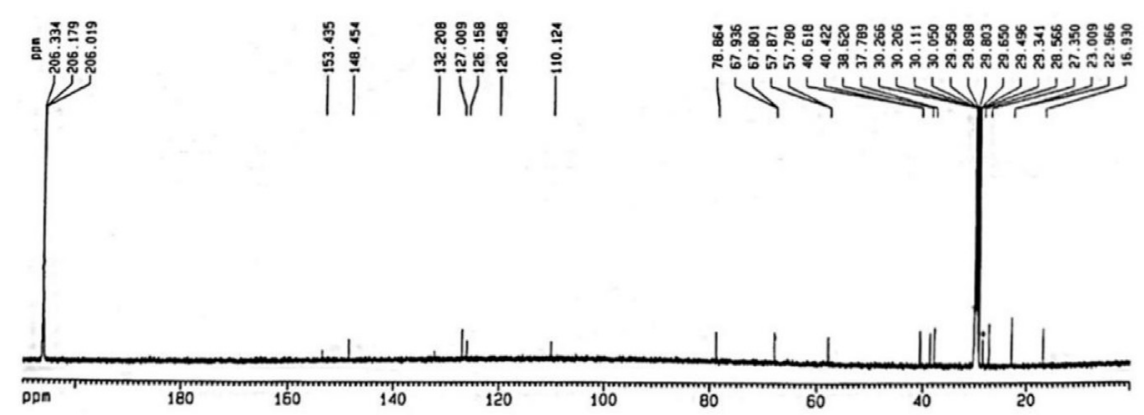

Fig. S7. ${ }^{13} \mathrm{C} N M R$ spectrum of $6 \alpha$-hydroxyhinokiol (3) in acetone- $d_{6}$ at $125 \mathrm{MHz}$.
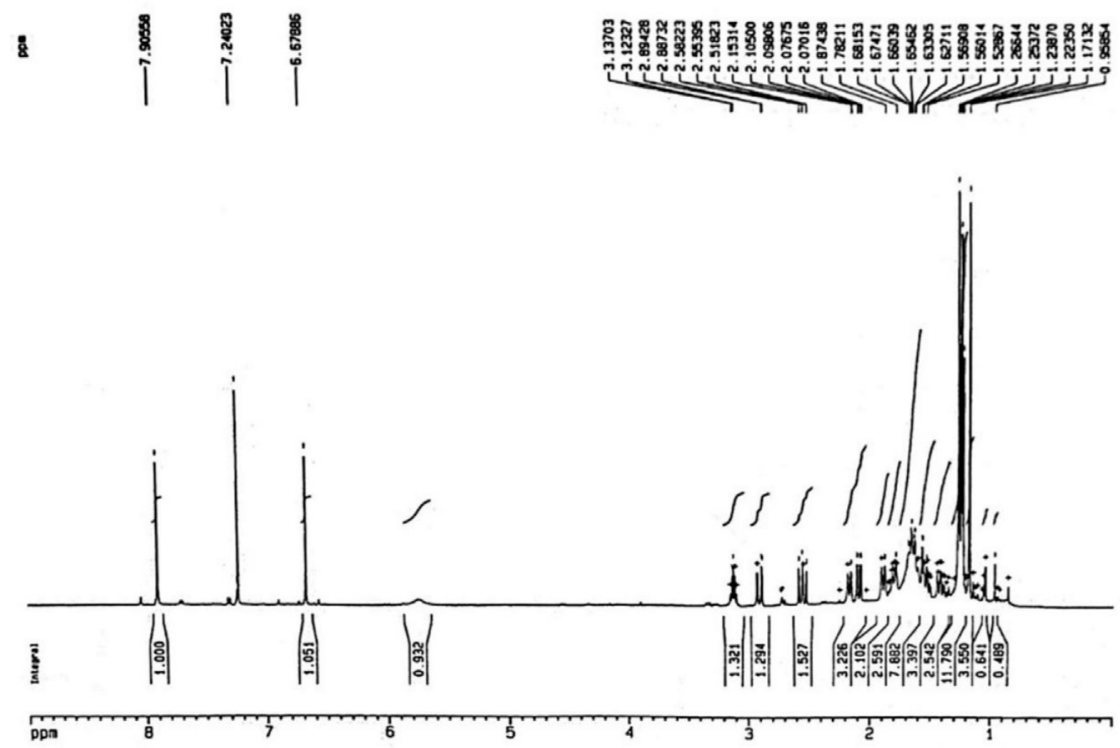

Fig. S8. ${ }^{1} \mathrm{H}$ NMR spectrum of $4 \alpha$-hydroxy-7-oxo-18-norabieta-8,11,13-triene-4 $\alpha$-ol (4a) in CDCl3 at $500 \mathrm{MHz}$. 


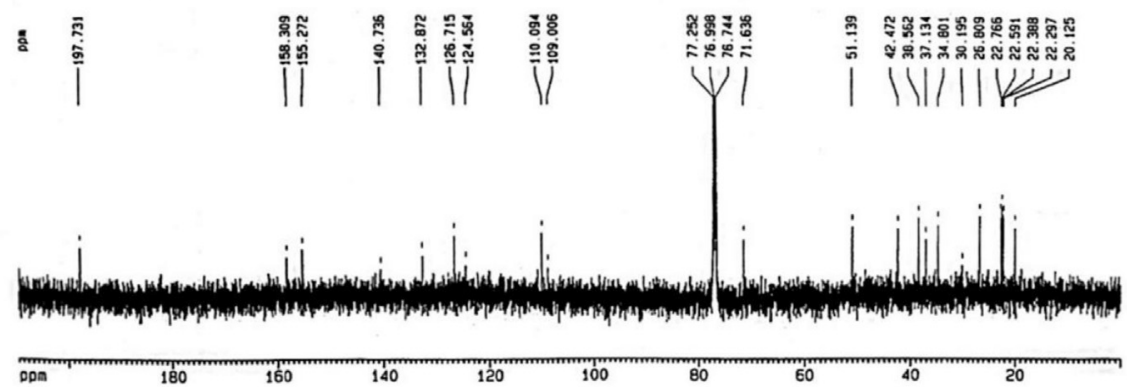

Fig. S9. ${ }^{13} \mathrm{C}$ NMR spectrum of $4 \alpha$-hydroxy-7-oxo-18-norabieta-8,11,13-triene- $4 \alpha-o l$ (4a) in CDCl3 at $125 \mathrm{MHz}$.
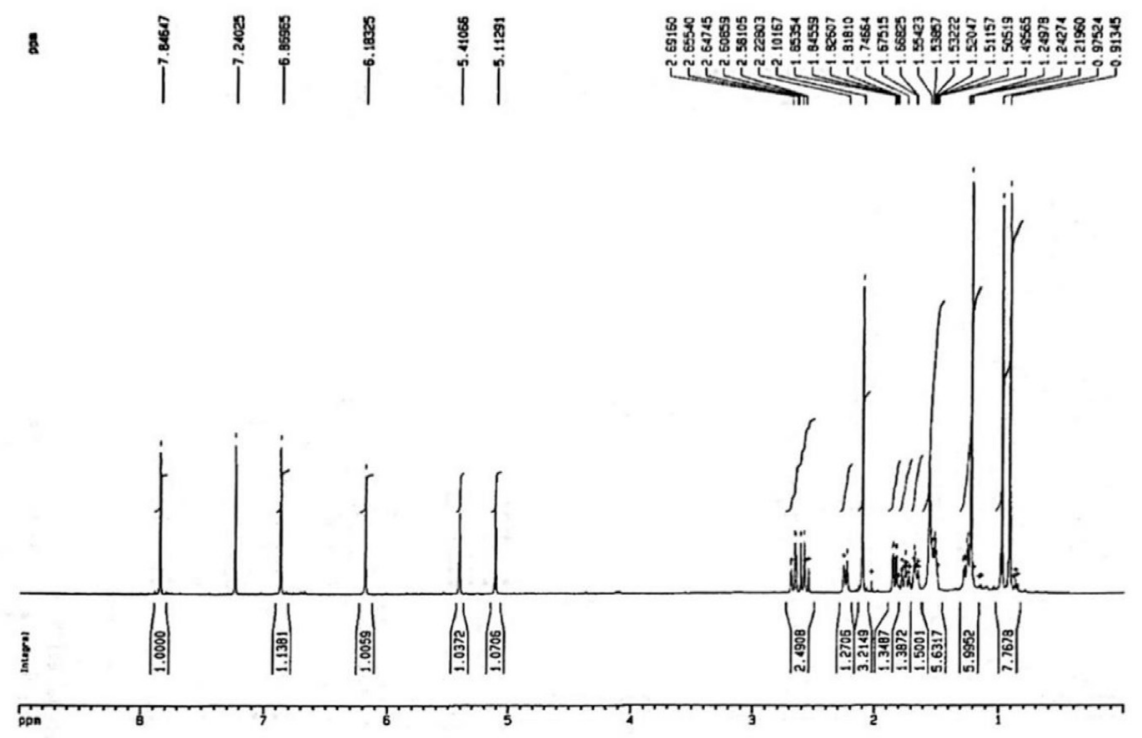

Fig. S10. ${ }^{1} \mathrm{H} \mathrm{NMR}$ spectrum of 15,16-dehydrosugiol (5) in $\mathrm{CDCl}_{3}$ at $500 \mathrm{MHz}$.

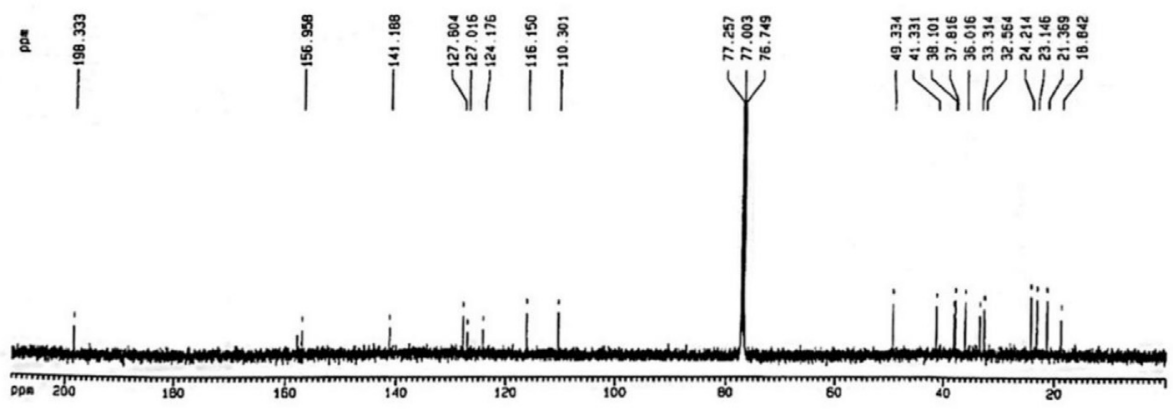

Fig. S11. ${ }^{13} \mathrm{C}$ NMR spectrum of 15,16-dehydrosugiol (5) in $\mathrm{CDCl}_{3}$ at $125 \mathrm{MHz}$. 


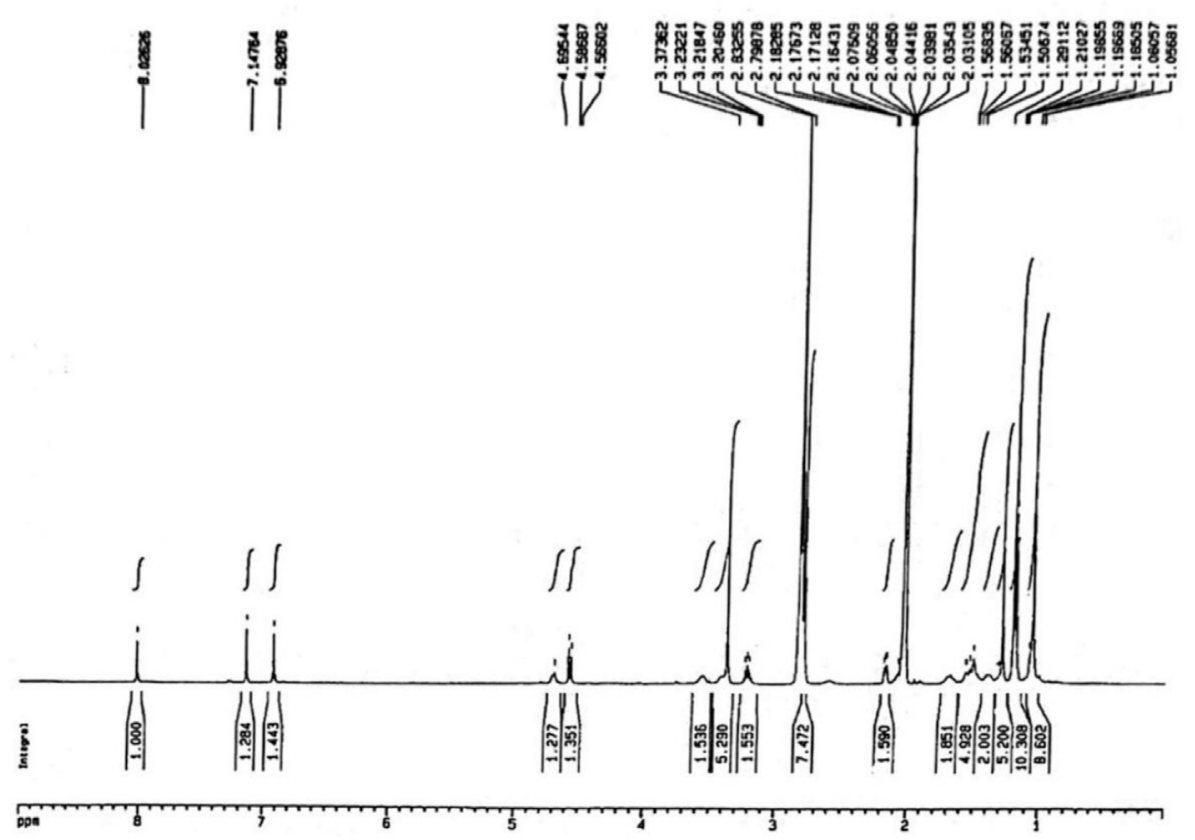

Fig. S12 ${ }^{1} \mathrm{H}$ NMR spectrum of 7-methoxy-6,7-secoabieta-8,11,13-triene-6,12-diol (6) in $\mathrm{CDCl}_{3}$ at $500 \mathrm{MHz}$.

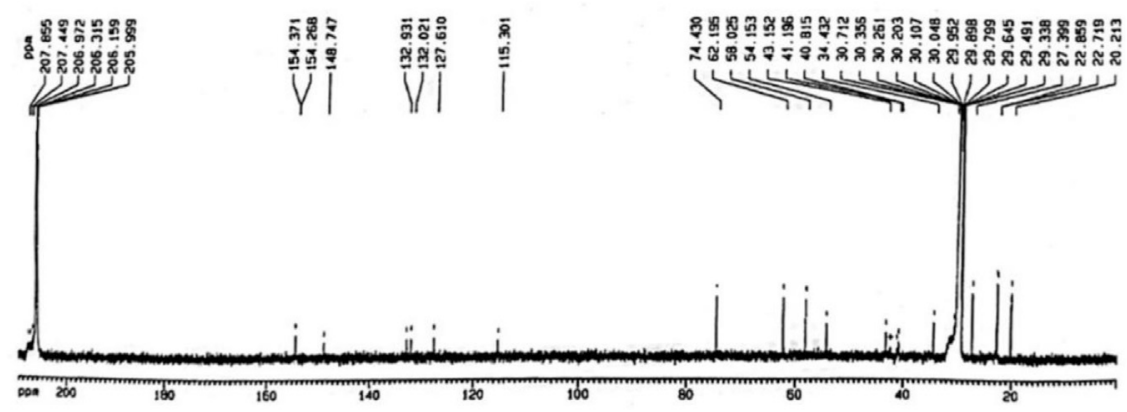

Fig. S13. ${ }^{13} \mathrm{C}$ NMR spectrum of 7-methoxy-6,7-secoabieta-8,11,13-triene-6,12-diol (6) in $\mathrm{CDCl}_{3}$ at $125 \mathrm{MHz}$.
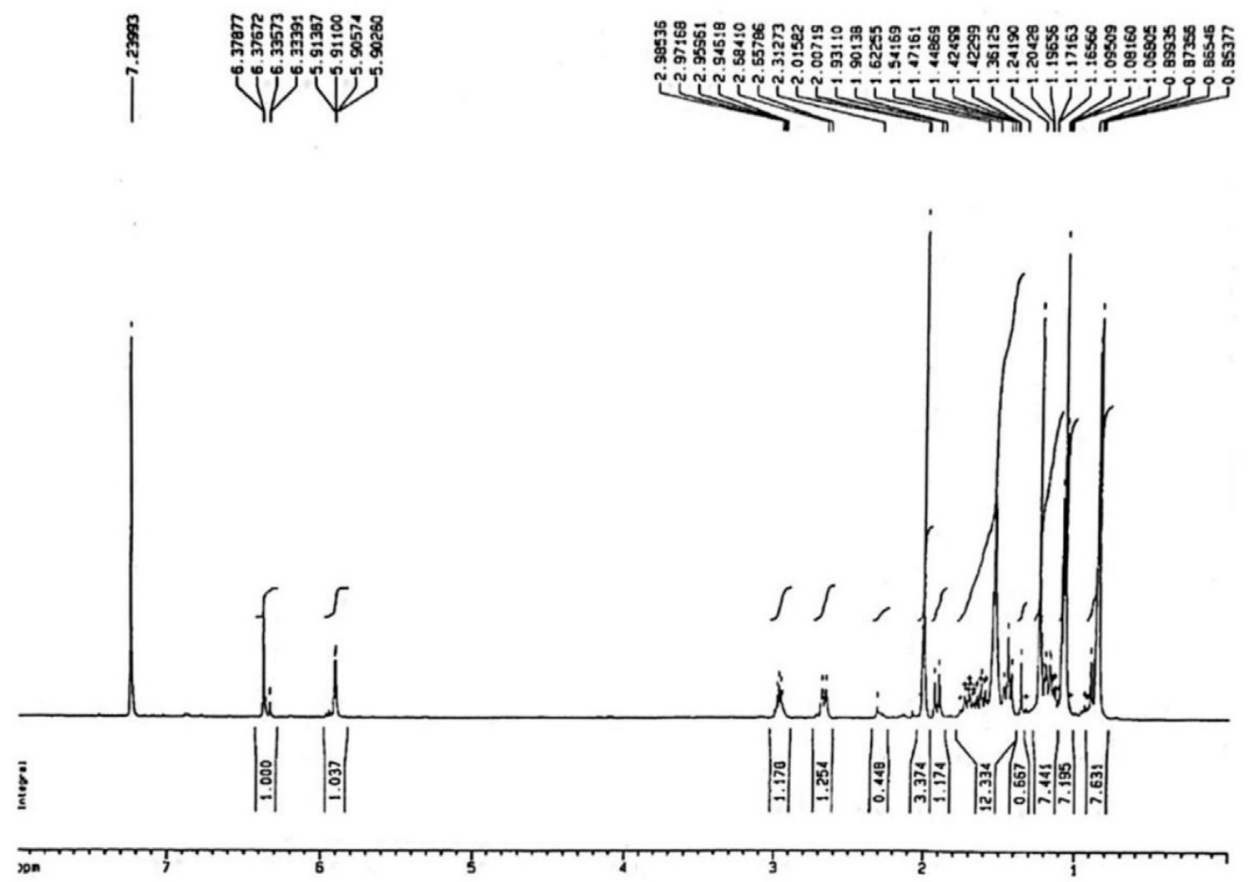

Fig. S14. ${ }^{1} \mathrm{H}$ NMR spectrum of $7 \alpha$-acetoxyabieta-8,12-diene-11,14-dione (7) in $\mathrm{CDCl}_{3}$ at $500 \mathrm{MHz}$. 


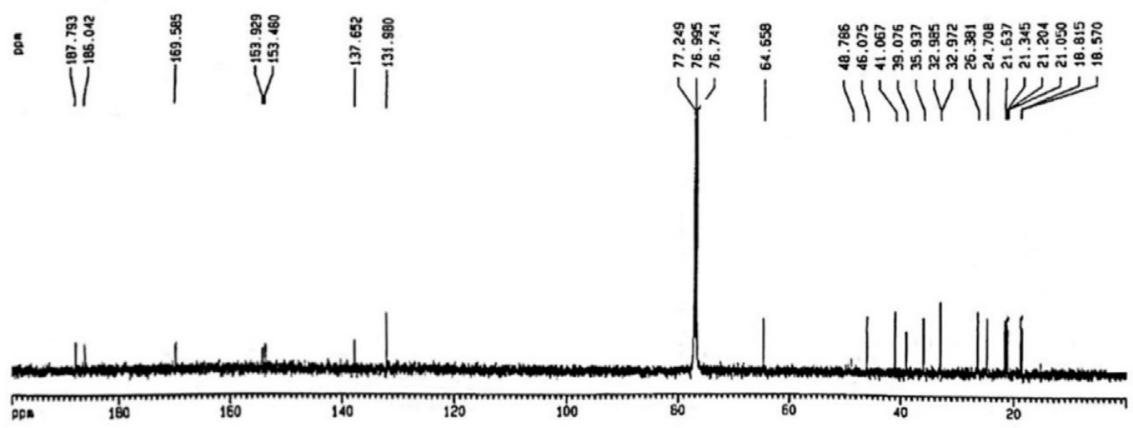

Fig. $S 15{ }^{13} \mathrm{C} N M R$ spectrum of $7 \alpha$-acetoxyabieta-8,12-diene-11,14-dione (7) in $\mathrm{CDCl}_{3}$ at $125 \mathrm{MHz}$.

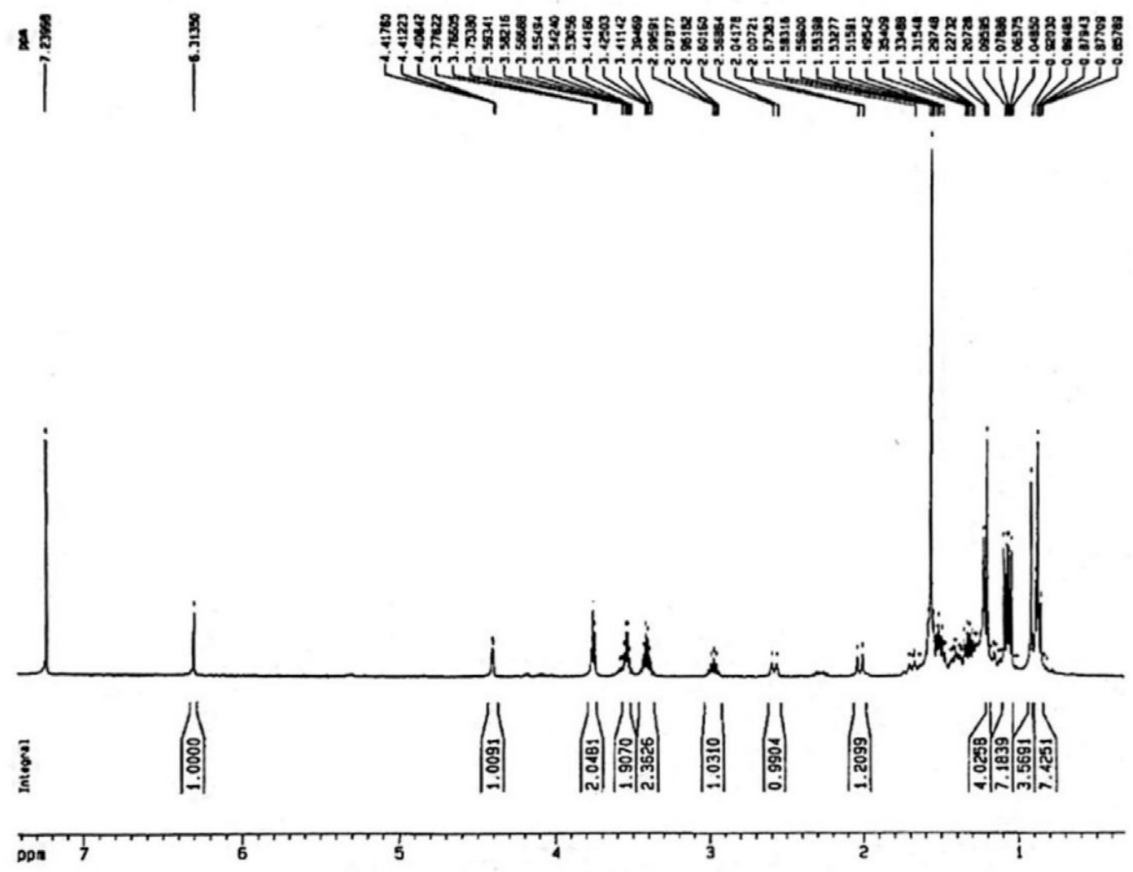

Fig. S16. ${ }^{1} \mathrm{H}$ NMR spectrum of $7 \alpha$-butyloxyethyloxyabieta-8,12-diene-11,14-dione (8) in $\mathrm{CDCl}_{3}$ at $500 \mathrm{MHz}$.

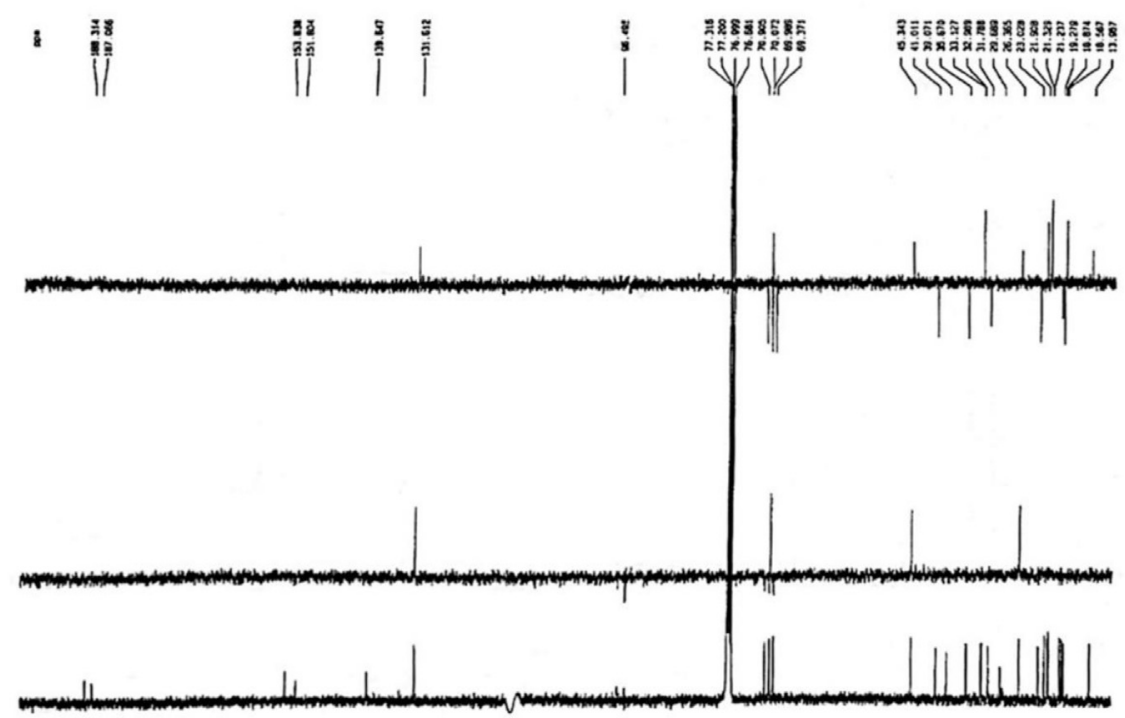

Fig. S17. DEPT spectrum of 7 $\alpha$-butyloxyethyloxyabieta-8,12-diene-11,14-dione (8). 


\section{References}

[1] Oh CM, Lee D, Kong HJ, Lee S, Won YJ, Jung KW, et al. Causes of death among cancer patients in the era of cancer survivorship in Korea: attention to the suicide and cardiovascular mortality. Cancer Med 2020;9:1741-52.

[2] Paduch R. The role of lymphangiogenesis and angiogenesis in tumor metastasis. Cell Oncol 2016;39:397-410.

[3] Shirouzu T, Watari K, Ono M, Koizumi K, Saiki I, Tanaka C, et al. Structure, synthesis, and biological activity of a C-20 bisacetylenic alcohol from a marine sponge Callyspongia sp. J Nat Prod 2013;76:1337-42.

[4] Wu XD, Wang SY, Wang L, He J, Li GT, Ding LF, et al. Labdane diterpenoids and lignans from Calocedrus macrolepis. Fitoterapia 2013;85:154-60.

[5] Wang SY, Wu JH, Cheng SS, Lo CP, Chang HN, Shyur LF, et al. Antioxidant activity of extracts from Calocedrus formosana leaf, bark, and heartwood. J Wood Sci 2004;50:422-6.

[6] Inamori Y, Sakagami Y, Morita Y, Shibata M, Sugiura M, Kumeda $Y$, et al. Antifungal activity of hinokitiol-related compounds on wood-rotting fungi and their insecticidal activities. Biol Pharm Bull 2000;23:995-7.

[7] Lo TB, Lin YT. Study on the extractive constituents from the wood of libocedrus formosana, Florin. I. Chin Chem Soc 1956;3: 30-5.

[8] Lin YT, Lin KT, Wang KT, Weinstein B. Phytochemical studies. Isolation of 5-ethyltropolone from Libocedrus formosana. Experientia 1966;22:140-1.

[9] Ichikawa N. Studies on the constitution of shonanic acid, one of the two characteristic volatile acids from the wood of Libocedrus formosana, Florin. V. Studies on the oxidation of dihydroshonanyl alcohol and the ozonolysis of shonanic acid. Bull Chem Soc Jpn 1937;12:258-66.

[10] Lee TH, Lee MS, Ko HH, Chen JJ, Chang HS, Tseng MH, et al. New furanone and sesquiterpene from the pericarp of Calocedrus formosana. Nat Prod Commun 2015;10:845-6.

[11] Hsieh CL, Shiu LL, Tseng MH, Shao YY, Kuo YH. Calocedimers A, B, C, and D from the bark of Calocedrus macrolepis var. formosana. J Nat Prod 2006;69:665-7.

[12] Lin YT, Liu KT. A study of the extractive constiuents from the wood of Libocedrus Formosana, Florin. VIII. The phenolic components. Shonanol, a new diterpene phenol. Chin Chem Soc 1965; 12:51-60.

[13] Hsieh CL, Tseng MH, Pan RN, Chang JY, Kuo CC, Lee TH, et al. Novel terpenoids from Calocedrus macrolepis var. formosana. Chem Biodivers 2011;8:1901-7.

[14] Hsieh YH, Chen KJ, Chien SC, Cheng WL, Xiao JH, Wang SY. ACAT inhibitory activity of exudates from Calocedrus macrolepis var. formosana. Nat Prod Commun 2012;7. $1934578 X 1200701206$.
[15] Hsieh CL, Tseng MH, Kuo YH. Formosadimers A, B, and C from the bark of Calocedrus macrolepis var. formosana. Chem Pharm Bull 2005;53:1463-5.

[16] Hsieh CL, Tseng MH, Shao YY, Chang JY, Kuo CC, Chang CY, et al. C35 terpenoids from the bark of Calocedrus macrolepis var. formosana with activity against human cancer cell lines. J Nat Prod 2006;69:1611-3.

[17] Hsien CL, Tseng MH, Pan RN, Chang JY, Kuo CC, Lee TH, et al. Labdanecaryophyllic acid, a novel cytotoxic C35 terpenoid from Calocedrus macrolepis var. formosana. Tetrahedron Lett 2011;52:515-7.

[18] Ho ST, Lin CC, Wu TL, Tung YT, Wu JH. Antitumor agent yatein from Calocedrus formosana Florin leaf induces apoptosis in non-small-cell lung cancer cells. J Wood Sci 2019;65:59.

[19] Chao LK, Hua KF, Hsu HY, Su YC, Chang ST. Bioactivity assay of extracts from Calocedrus macrolepis var. formosana bark. Bioresour Technol 2006;97:2462-5.

[20] Ho CL, Tseng YH, Wang EI, Liao PC, Chou JC, Lin CN, et al. Composition, antioxidant and antimicrobial activities of the seed essential oil of Calocedrus formosana from Taiwan. Nat Prod Commun 2011;6:133-6.

[21] Chang HT, Cheng YH, Wu CL, Chang ST, Chang TT, Su YC. Antifungal activity of essential oil and its constituents from Calocedrus macrolepis var. formosana Florin leaf against plant pathogenic fungi. Bioresour Technol 2008;99:6266-70.

[22] Chang FR, Wang SW, Chen SR, Lee CY, Sheu JH, Cheng YB. Aleuritin, a novel dinor-diterpenoid from the twigs of Aleurites moluccanus with an anti-lymphangiogenic effect. Org Biomol Chem 2020;18:7892-8.

[23] Chen SR, Wang SW, Chang FR, Cheng YB. Anti-lymphangiogenic alkaloids from the zoanthid Zoanthus vietnamensis collected in taiwan. J Nat Prod 2019;82:2790-9.

[24] Haslinger E, Michl G. Synthese von (+)-taxodion. Liebigs Annalen der Chemie 1989;1989:677-86.

[25] Chao KP, Hua KF, Hsu HY, Su YC, Chang ST. Anti-inflammatory activity of sugiol, a diterpene isolated from Calocedrus formosana bark. Planta Med 2005;71:300-5.

[26] Tan N, Kaloga M, Radtke OA, Kiderlen AF, Öksüz S, Ulubelen $\mathrm{A}$, et al. Abietane diterpenoids and triterpenoic acids from Salvia cilicica and their antileishmanial activities. Phytochemistry 2002;61:881-4.

[27] Nasipuri D, Guha M. 821. Synthetical studies in the diterpene series. Part II. Synthesis of $( \pm)$-sugiyl methyl ether and related compounds. J Chem Soc 1962:4248-52.

[28] Valverde S, Escudero J, Cristóbal López J, Ma Rabanal R. Two terpenoids from Salvia bicolor. Phytochemistry 1985;24: $111-3$

[29] Kuo YH, Chen $\mathrm{CH}$, Huang SL. New diterpenes from the heartwood of Chamaecyparis obtusa var. formosana. J Nat Prod 1998;61:829-31. 